\title{
Working
}

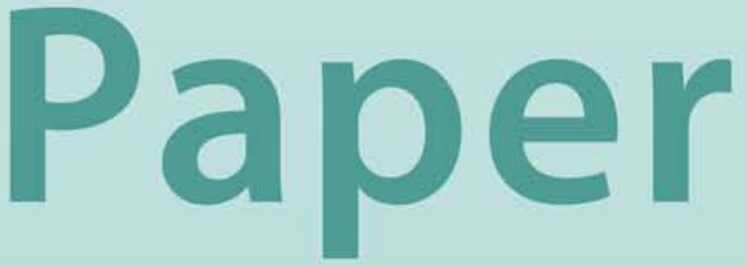


Spillovers to Central America in Light of the Crisis: What a Difference a Year Makes

Andrew Swiston 


\title{
IMF Working Paper
}

Western Hemisphere Department

\section{Spillovers to Central America in Light of the Crisis: What a Difference a Year Makes}

\author{
Prepared by Andrew Swiston
}

Authorized for distribution by Andreas Bauer

February 2010

\begin{abstract}
* $^{*}$
This Working Paper should not be reported as representing the views of the IMF. The views expressed in this Working Paper are those of the author(s) and do not necessarily represent those of the IMF or IMF policy. Working Papers describe research in progress by the author(s) and are published to elicit comments and to further debate.

This paper investigates Central America's external linkages over the last fifteen years of increased integration in light of the 2008-09 global recession. Using structural VAR models, it is found that a one percent shock to U.S. growth shifts economic activity in Central America by 0.7 to 1 percent, on average. Spillovers from global shocks and the rest of the region also affect activity in some countries. Spillovers are mostly transmitted through advanced country financial conditions and fluctuations in external demand for Central American exports. Shocks to advanced economies associated with the 2008-09 financial crisis lowered economic activity in the region by 4 to 5 percent, on average, accounting for a majority of the observed slowdown. The impact was almost twice as large as elasticities estimated on pre-crisis data would have predicted. These results underscore the importance of operating credible policy frameworks that enable a countercyclical policy response to external shocks.
\end{abstract}

JEL Classification Numbers: E32, F15, F40

Keywords: Central America, Spillovers, Economic Integration, Business Cycles, Vector Autoregression

Author’s E-Mail Address: aswiston@imf.org

\footnotetext{
* Many thanks for helpful comments to Miguel Savastano, Andreas Bauer, Alfred Schipke, Mario Dehesa, other colleagues in the IMF's Western Hemisphere Department, and seminar participants in the IMF. All remaining errors are the author's.
} 


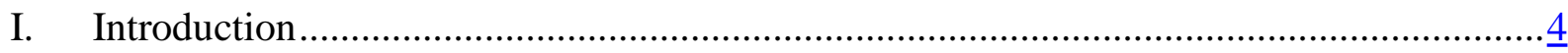

II. Trends in Economic Integration..............................................................................

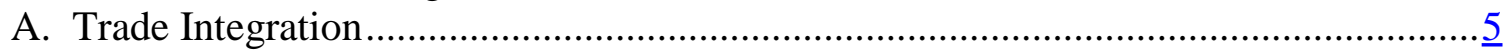

B. Financial Integration ..................................................................................

C. Remittance Flows...................................................................................................11

III. Business Cycle Co-Movement.....................................................................................

A. Previous Work on Central American Business Cycles ................................................ 13

B. Influence of the U.S. Cycle................................................................................

C. Synchronization of Central American Cycles...............................................................15

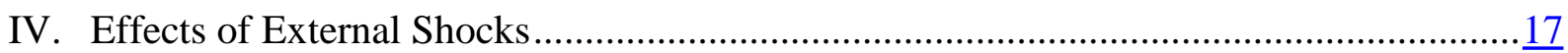

A. Structural VAR Methodology and Data ………………………………………..... $\frac{18}{20}$

B. Response of Central American Activity to External Shocks ......................................믄

C. Spillovers to Individual Central American Countries................................................21

D. Spillovers Within Central America................................................................21

E. Geographic Drivers of Central American Business Cycles ........................................23

F. Elasticities of Central American Activity to External Shocks......................................24

G. Impact of the 2008-09 Crisis ....................................................................................

V. Transmission Channels for External Growth Spillovers ...................................................29

A. Identifying the Channels .........................................................................................

B. Decomposition of Spillovers to Central America …………………………………....

VI. Summary and Conclusions ………………………..................................................

Appendix I: Constructing GDP-Consistent Quarterly Indicators of Economic Activity ...........34

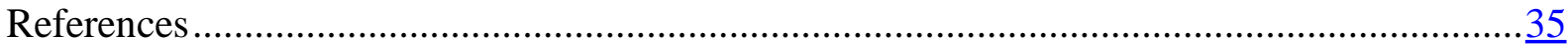

Figures

1. Trade Integration: Major Trading Partners ................................................................... 6

2. Trade Integration: Exports to GDP ………………..................................................

3. Trade Volume Co-Movement ....................................................................................

4. Financial Integration: Cross-Border Asset Holdings ........................................................ 10

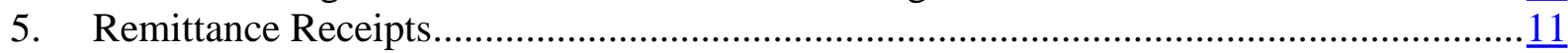

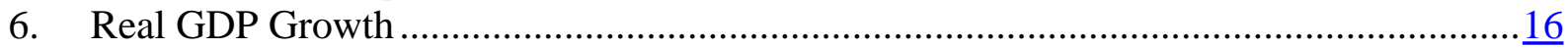

7. Real GDP Spillovers From Major Regions ……………………………………….....

8. Real GDP Spillovers to Individual Countries..............................................................22

9. Real GDP Spillovers Within Central America ………………………….....................23

10. Model Performance During the Crisis ......................................................................

11. Impact of Advanced Country Shocks During the Crisis...................................................27

12. Decomposition of Real GDP Spillovers from the United States ....................................... 
Tables

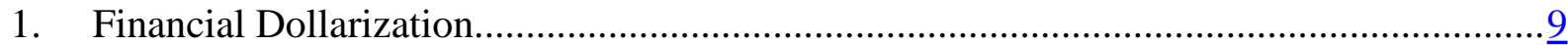

2. Remittance Flows in Ratha and Shaw (2007) ......................................................12

3. Real GDP Growth Correlations With the United States ...........................................15

4. Volatility of Economic Growth ...................................................................... $\frac{15}{17}$

5. Real GDP Growth Correlations Within Central America............................................ $\frac{17}{24}$

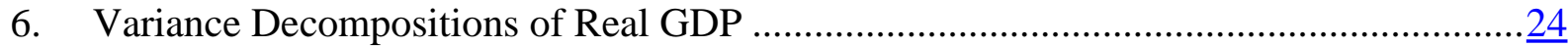

7. Elasticities of Central American Activity to External Shocks ......................................24

8. Correlations of Model Residuals .....................................................................28

9. Volatility and Correlations of Activity Indicators, 1995-2008 ................................... 


\section{INTRODUCTION}

The global recession of 2008-09 and ongoing recovery bring to the forefront the depth and nature of Central America's linkages to other economies, both within the region (see the works contained in Desruelle and Schipke, 2008; and Brenner, 2006) and outside of the region (see Baroni, 2008; Roache, 2008a; Kim and Papi, 2005; Kose, Rebucci, and Schipke, 2005). ${ }^{1}$ What has been the impact of the global shock on the region, through which transmission channels has it occurred, and how will the nature of the global recovery affect growth in the region going forward?

To provide answers to these questions, this paper investigates Central America's external linkages in light of the last decade and a half of increased integration. The paper uses a structural vector autoregressive (SVAR) framework similar to the model introduced in Bayoumi and Swiston (2009), which incorporates interactions among major regions outside Central America, allows activity in Central America as a whole to affect each individual country, and accommodates a decomposition of real GDP spillovers into the channels responsible for their transmission. Unlike other studies on the region, the analysis is conducted using high-frequency quarterly data, which allows it to capture the lag structure inherent in the transmission of economic activity across borders. The period under investigation is restricted to that coinciding with the opening up of Central America to international trade and financial flows, which allows it to more fully reflect the external linkages of the economies of the region as they are today.

This study finds significant effects from the U.S. economy on the region as a whole as well as on most individual countries. A one percent shock to U.S. growth shifts economic activity in Central America by 0.7 to 1 percent, on average, generally higher than studies including earlier decades in the analysis, but in line with elasticities estimated since 1990 by Fiess (2007). Spillovers from global shocks are of a similar order of magnitude. These spillovers are mostly transmitted through the impact of advanced country financial conditions on growth abroad and within the region, or through fluctuations in external demand for Central American exports. Activity elsewhere in Central America is also an important driver of activity in some countries, above and beyond the common response to external spillovers. This reflects increased intra-regional integration in recent decades. These results underscore the importance of operating credible policy frameworks that enable a countercyclical policy response to external shocks.

Shocks to advanced economies associated with the 2008-09 financial crisis are found to have lowered economic activity in the region by about 4 to 5 percent, on average, accounting for a majority of the observed slowdown. Almost half of this impact was a surprise given elasticities estimated on pre-crisis data. The extent to which the impact of the recent crisis was a surprise highlights an important caveat to the findings of this paper. Recent external shocks are of a size and breadth not seen since the end of the Second World War, meaning

\footnotetext{
${ }^{1}$ This paper uses the term Central America as shorthand to refer to the group of countries comprising Costa Rica, the Dominican Republic, El Salvador, Guatemala, Honduras, Nicaragua, and Panama.
} 
that the lessons drawn from the impact of this episode may not apply as broadly outside times of crisis. Nevertheless, the sharp simultaneous downturn seen in most of Central America illustrates the potential impact of external spillovers in future such episodes. Furthermore, if the rapid structural change seen over the period under analysis has further increased Central America's external linkages, the sensitivity of the economies of the region to external shocks could remain high even outside of recessions.

The rest of the paper is organized as follows: Section II outlines recent trends in economic integration; Section III examines business cycle synchronization, both among the countries of Central America and with the United States; Section IV estimates the effects of external shocks on Central American economic activity, and assesses the impact of the global recession; Section $\mathrm{V}$ investigates the channels through which shocks to other economies are transmitted to the region; and Section VI concludes.

\section{TRENDS IN ECONOMIC INTEGRATION}

This section examines Central America's effective integration with the global economy in three areas - trade, financial linkages, and remittances, with a focus on the situation as it stood in the years immediately preceding the recent global recession.

\section{A. Trade Integration}

The Central American region's main trade ties are with the United States, reflecting the region's close geographical proximity, recent free trade agreements, and previous preferential trading arrangements (Figure 1). ${ }^{2}$ About 60 percent of all goods exports are to the United States, ranging from under half for Costa Rica, Guatemala, and Panama to over two thirds for the Dominican Republic and Honduras. Trade links within Central America are also sizable, representing 20 percent of exports on average, outside of the Dominican Republic and Panama. Intra-regional linkages are strongest for El Salvador and Guatemala. Other major trading partners include other advanced economies and emerging Western Hemisphere countries.

Integration in global product markets has been increasing over time, with the share of goods exports in GDP rising from 21 percent over the 1990-94 period to 27 percent since 2000 (Figure 2). The rise of Nicaragua's export share was particularly pronounced, increasing by nearly 20 percent of GDP. The export share also rose significantly in Costa Rica, El Salvador, and Honduras. Most of the increase in export shares occurred by the mid1990s, except for Nicaragua. The breakdown between U.S. and rest-of-world trade has remained relatively stable over time.

\footnotetext{
2 The CAFTA-DR free trade agreement was implemented between 2004 and 2008 by the signatory countries: Costa Rica, the Dominican Republic, El Salvador, Guatemala, Honduras, and Nicaragua. Panama has a similar free trade agreement with the United States but does not comprise part of the CAFTA-DR bloc. Implementation of these agreements is likely to spur further integration with the United States, although the already sizable trade linkages suggest that the impact could be less dramatic than, for example, that of NAFTA on Mexico.
} 
Figure 1. Trade Integration: Major Trading Partners

(Goods exports as percent of total, average 2003-2007)

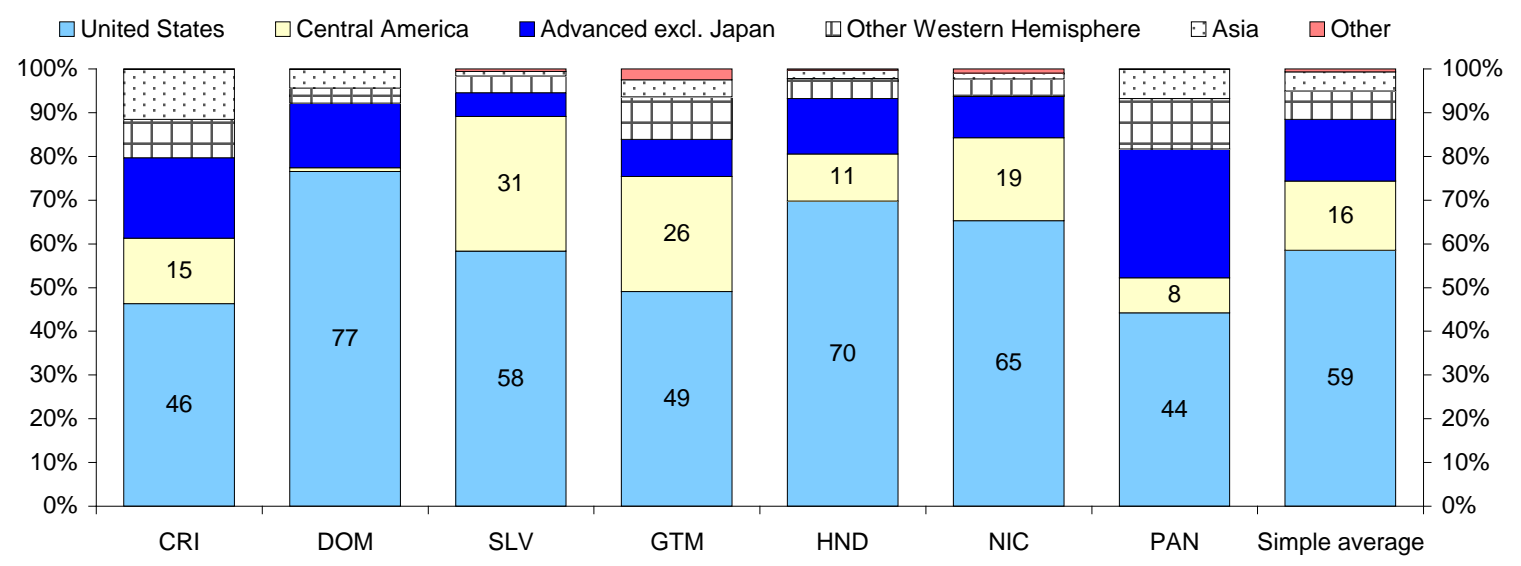

Sources: IMF, Direction of Trade Statistics; Haver Analytics; IMF, World Economic Outlook; and IMF staff calculations.

Trade in services is another important source of economic integration, accounting for over 10 percent of GDP for Costa Rica, the Dominican Republic, and Panama. However, trade in services has not increased as rapidly as a share of the economy in the last two decades as has merchandise trade, as the simple average rose from 8.7 percent of GDP from 1990-94 to 10.1 percent of GDP from 2000-07. Data on trading partners in services is restricted to tourism, for which Baroni (2008) found that U.S. tourists accounted for between 20 and 45 percent of visitors to the region in 2005 (excluding the Dominican Republic, which was not included in the study). Visitors from within Central America comprised the majority of tourists in El Salvador, Guatemala, Honduras, and Nicaragua, but there is no breakdown of the dollar value of receipts by origination of tourists. The lack of comprehensive quarterly data on services trade for several countries precludes it from being presented separately in the quantitative analysis in later sections.

Several empirical studies have concluded that deepening trade ties intensify business cycle synchronization. Calderón, Chong, and Stein (2006) conducted a comprehensive study focused on developing countries, and found a positive, significant relationship between trade intensity and output co-movement among 147 countries over four decades. Fiess (2007) analyzes Central American and industrial countries and finds a mild positive relationship between trade intensity and output co-movement. Several studies focusing on Mexico-U.S. synchronization since the inception of NAFTA conclude that tighter trade linkages have increased Mexico's degree of correlation with the U.S. economy. ${ }^{3}$ Thus, one would

\footnotetext{
${ }^{3}$ See, for example, Torres and Vela (2003); Kose, Meredith, and Towe (2004); Chiquiar and Ramos-Francia (2005); Lederman, Maloney, and Servén (2005); Bergin, Feenstra, and Hanson (2009); Fiess (2007); Sosa (2008); and Swiston and Bayoumi (2008). The latter study also finds that greater U.S.-Canada integration increased the synchronicity of those countries' business cycles.
} 
Figure 2. Trade Integration: Exports to GDP (Goods exports as percent of GDP, period averages)
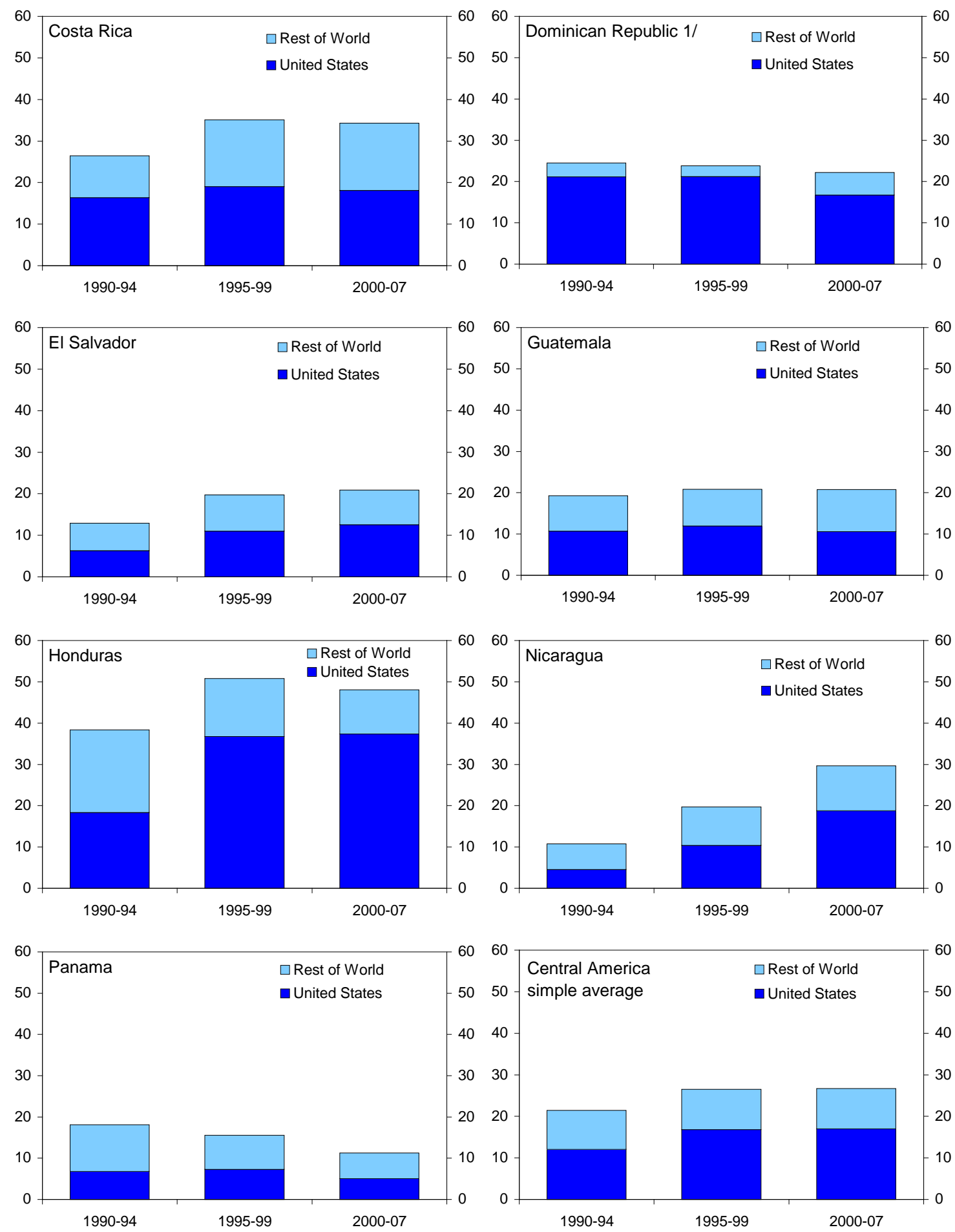

Sources: Haver Analytics; IMF, Direction of Trade Statistics; IMF, World Economic Outlook; IMF, International Financial Statistics; and IMF staff calculations.

1/ Data begin in 1993. 
expect that the rising degree of integration of Central America with global product markets would have resulted in a greater correlation between domestic and foreign economic activity, especially that in the United States. Focusing narrowly on trade volumes, co-movement between U.S. import volumes and Central American export volumes has indeed risen for every country since the 1990s, although the average correlation of 0.5 is below Mexico's correlation of 0.8 (Figure 3).

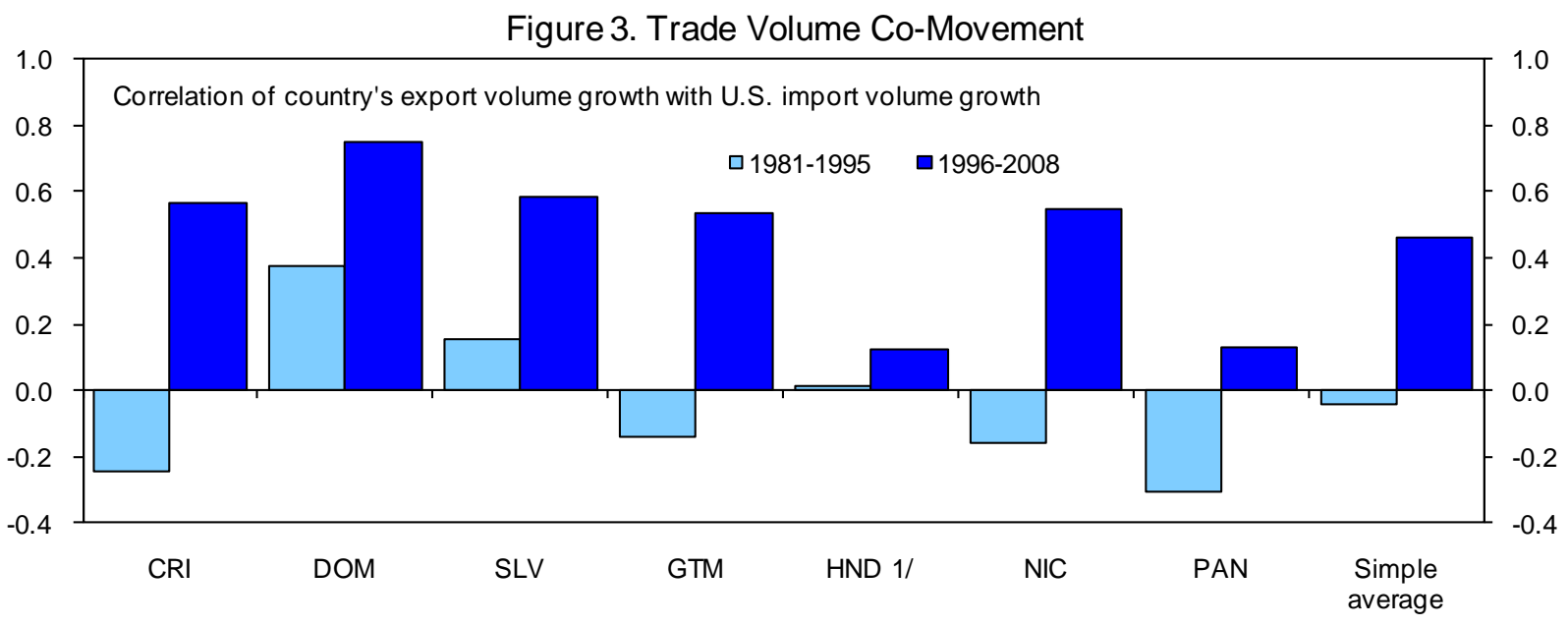

Sources: IMF, World Economic Outlook; and IMF staff calculations. 1/ Excludes 1999 because of the effects of Hurricane Mitch.

\section{B. Financial Integration}

While financial linkages across countries could take several different forms, three features of the financial systems in Central America would tend to influence the channels of transmission: their bank-based financial systems (in particular the involvement of foreign banks); their relatively high asset and liability dollarization; and the rising exposure of the economies to cross-border capital flows.

Financial conditions in other regions could feed through to Central America by affecting the lending capacity of multinational financial institutions (see Árvai, Driessen, and Ötker-Robe, 2009, for example). Commercial banks are the dominant providers of credit in the region, accounting for a significant majority of financial intermediation in all countries (Shah and others, 2008; Brenner, 2006). While involvement of global financial institutions (outside of Panama) was low through the early part of the 2000s, regional financial groups comprised a significant share of the financial system in El Salvador and Nicaragua (Morales and Schipke, 2005). Foreign acquisitions of regional and domestic banks picked up beginning in 2004, and foreign-owned banks now account for roughly 30 percent of commercial bank assets in Costa Rica, Honduras, and Nicaragua, and over 90 percent of assets in El Salvador. The recent increase in foreign ownership of the region's financial institutions means that this channel's influence is probably less evident in the historical data. 
Dollarization of financial system assets or liabilities constitutes a direct channel of transmission of financial conditions in other regions, predominantly the United States. In addition, movements in U.S. interest rates should change the rates prevailing on dollar-denominated instruments in the region. Panama has been officially dollarized for over 100 years, while El Salvador became officially dollarized in 2001. Dollarized instruments comprise the majority of financial assets and liabilities in Nicaragua, and over 40 percent in Costa Rica, with lower levels of dollarization in the Dominican Republic, Guatemala, and Honduras (Table 1). Historical data on financial system assets are lacking, but liability dollarization, at least, has increased since 1990 throughout the region.

Financial integration as measured by cross-border asset holdings has been on the rise since the mid-1990s, with average external liabilities in the region rising from 40 to 55 percent of GDP (Figure 4). ${ }^{4}$ Data on gross capital flows paint a similar picture of increasing integration. Financial integration appears to be less centered around the United States than is trade, as U.S. claims on Central America only comprise about 20 percent of total external liabilities. ${ }^{5}$ This amounts to about 12 percent of GDP, on average, up from 5 percent in 1994. Most of this investment is concentrated in FDI and bank lending, with securities holdings relatively small because of the lack of deep, liquid markets (Shah and others, 2008). Transmission of economic activity via cross-holdings of financial assets or cross-border capital flows could work in multiple ways. For example, movements in foreign interest rates affect interest payments and the external financing options of agents in Central America, fluctuations in foreign equity prices and interest rates alter foreign firms' capacity to engage in FDI, and capital flows have been shown to depend significantly on advanced country financial and economic conditions (Reinhart and Reinhart, 2008). Imbs (2006) and Schiavo (2008) find larger output correlations in countries where there is a higher degree of bilateral financial integration, as measured by cross-holdings of financial assets.

\footnotetext{
${ }^{4}$ Honduras and Nicaragua are excluded from the discussion of the regional average, as there are breaks in the data for these countries because of external debt forgiveness.

${ }^{5}$ This number may represent a lower bound because of offshore financial center bias in the bilateral holdings data. As of end-2006, offshore financial centers held over 30 percent of the region's portfolio liabilities.
} 
Figure 4. Financial Integration: Cross-Border Asset Holdings

(External financial liabilities as percent of GDP, period averages)
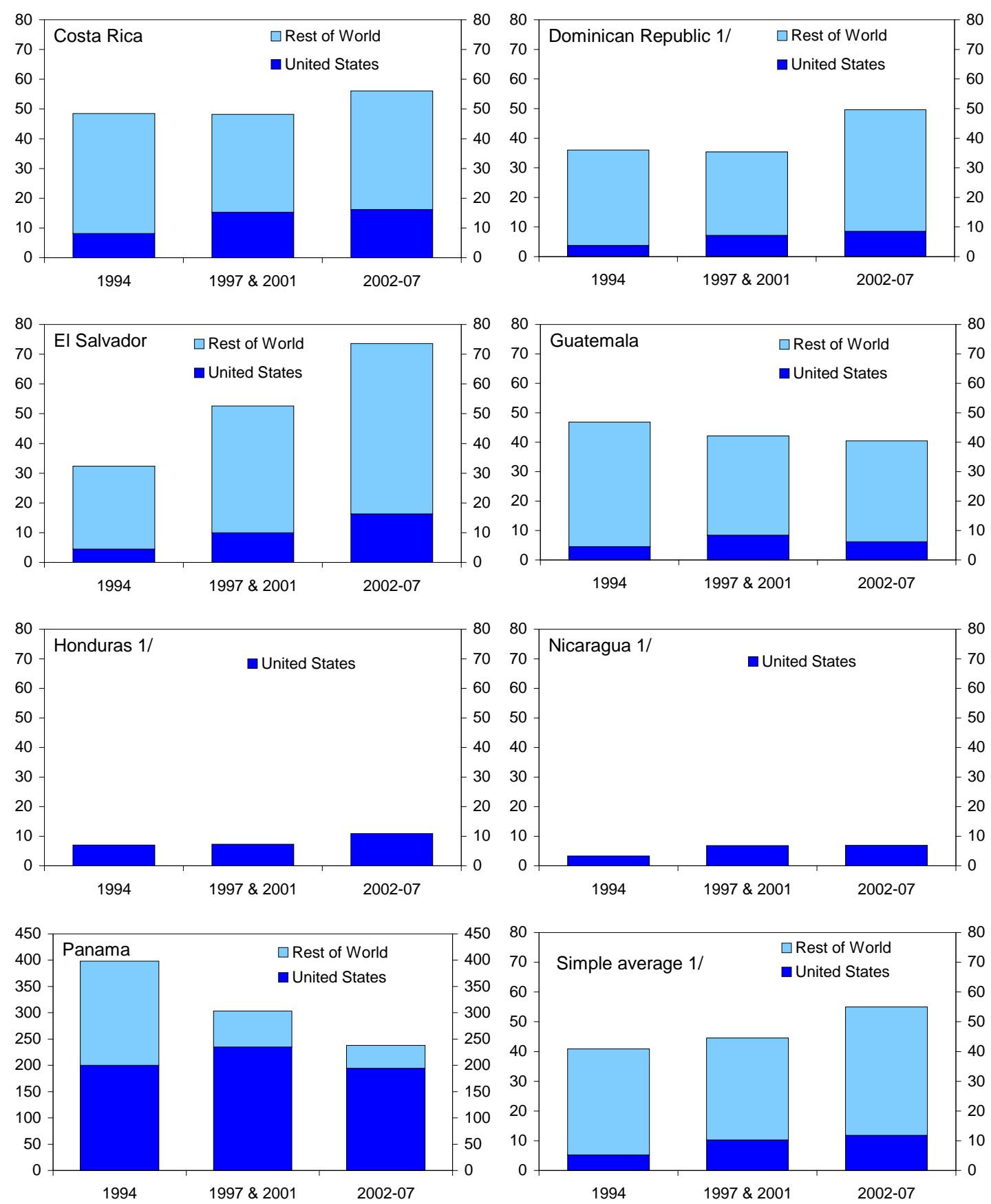

Sources: Bureau of Economic Analysis; United States Treasury; Bank for International Settlements; Haver Analytics; IMF, World Economic Outlook; IMF, International Financial Statistics; and IMF staff calculations. 1/ Rest of World holdings not shown for Honduras and Nicaragua because of breaks in series on account of debt relief. Honduras, Nicaragua, and Panama are excluded from the regional average (the latter given its sizable offshore financial center). 


\section{Remittance Flows}

Remittance receipts in Central America have grown rapidly since 2000, exceeding 8 percent of GDP on average, from 3 percent of GDP in the 1990s (Figure 5). A time series breakdown of the source countries is not available, but Ratha and Shaw (2007) use a geographic decomposition of the residence of migrants, along with host and recipient country income levels, to construct a matrix of bilateral remittance flows. They estimate that 80 percent of remittance flows into Central America originate in the United States (Table 2). Intra-region flows are only significant from Costa Rica to Nicaragua. ${ }^{6}$

Figure 5. Remittance Receipts

(Workers' remittances receipts as percent of GDP, period averages)
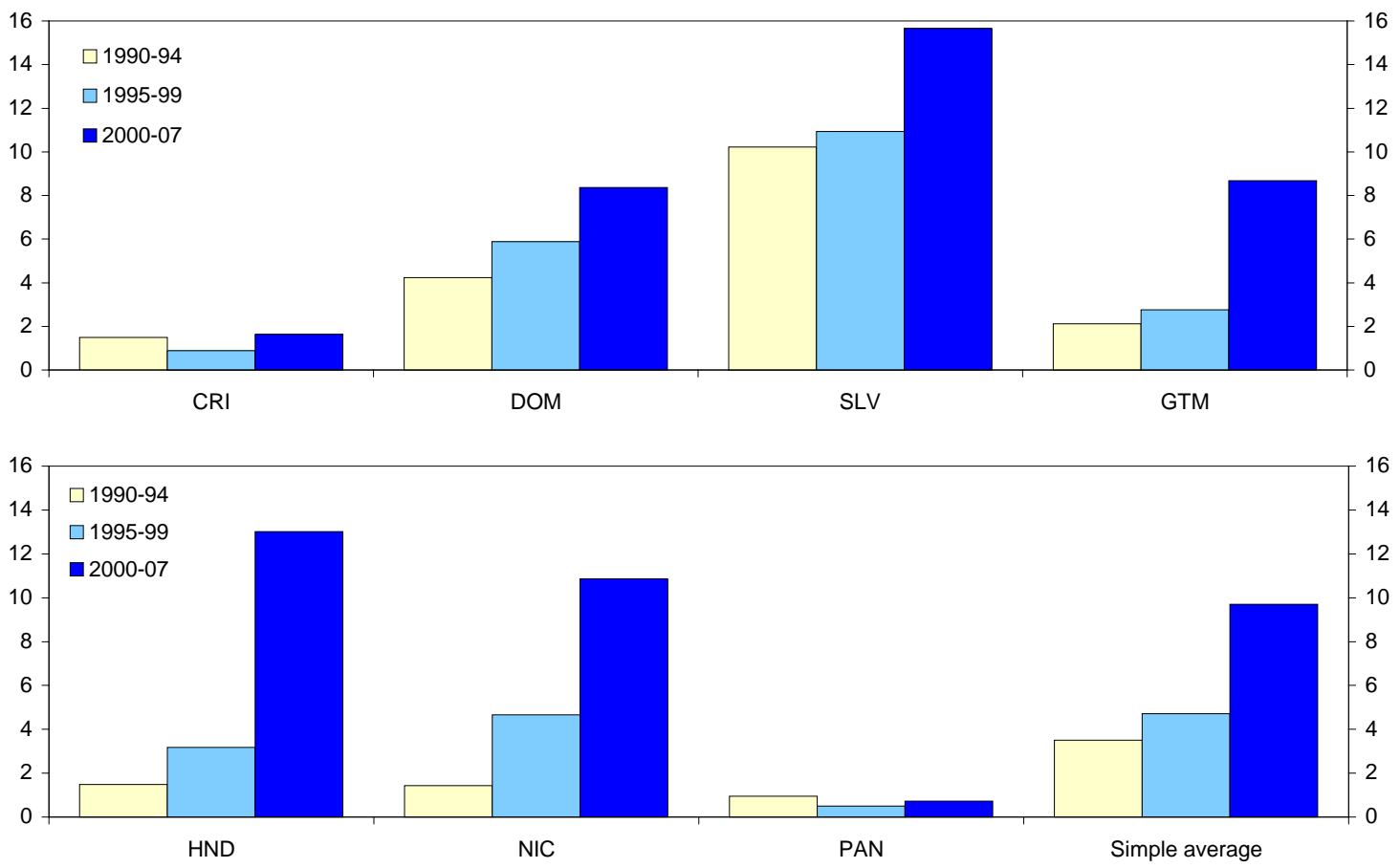

Sources: Haver Analytics; IMF, World Economic Outlook; IMF, International Financial Statistics; National Sources; and IMF staff calculations.

\footnotetext{
${ }^{6}$ Improvement in data quality over time could be one factor in the measured increase in remittance flows. As the costs of transferring remittances through formal channels have declined, the accuracy of official statistics has increased because they capture remittances through formal channels better than those through informal channels (World Bank, 2005). This effect would only occur gradually, and thus unfortunately appear in the data as extended high trend growth in remittances, which complicates analysis of the determinants and effects of remittances at higher frequencies.
} 
Table 2. Remittance Flows in Ratha and Shaw (2007)

(source of remittance inflows in 2005, percent of total)

\begin{tabular}{lcc|}
\hline & United States & Other Central America \\
\hline Costa Rica & 74 & 7 \\
Dominican Republic & 80 & 0 \\
El Salvador & 88 & 2 \\
Guatemala & 87 & 1 \\
Honduras & 89 & 3 \\
Nicaragua & 61 & 30 \\
Panama & 81 & 5 \\
Simple average & 80 & 7 \\
\hline Source: Ratha and Shaw, 2007. & & \\
\hline
\end{tabular}

If remittances are tied to employment and wage levels in the source country and boost expenditure in the recipient country, then they provide a direct positive link between economic activity abroad and in Central America. However, this positive relationship could in theory be offset by appreciation of the recipient country's real exchange rate, or a reduction in the domestic labor supply, and there is no consensus in the literature on the effect of remittance receipts on economic activity in the recipient country (Chami and others, 2008; Sayan, 2006; World Bank, 2005). Thus, the role of remittance flows as a transmission channel for the spillover of economic activity is an issue for empirical investigation.

Empirical evidence on the existence of a link between economic activity in the source country and remittance outflows is mixed. Roache and Gradzka (2007) find little support for a strong link between aggregate U.S. business cycles and remittances to Central or South America. At a macro level, the correlation between real growth in remittances receipts and real GDP growth in Central America is only 0.1. Magnusson Bernard (2009) focuses on remittances to Mexico and El Salvador and activity indicators in U.S. states with high concentrations of immigrants from those countries, and does find a positive relationship between state-level economic conditions and those countries’ remittance receipts.

Similarly, the effects of remittances on recipient country growth, as reviewed by Chami and others (2008), are also unclear. These authors fail to find a strong impact in a growth regression framework, while Sayan (2006) finds that receipts are typically acyclical with respect to economic activity in the recipient country. The global recession and recovery may shed more light on both the role of source country conditions and the impact of remittances on the destination country, as prior to this episode the cyclical variation in the official data was obscured by the upward structural shift in the level of remittance flows.

\section{Business CyCLE Co-Movement}

This section establishes the stylized facts of business cycle co-movement among Central American countries and between the region and the U.S. economy. Previous work has generally been done on annual real GDP data, with some use of monthly activity indicators. 
Use of either annual or monthly data has its drawbacks. The former neglects within-year dynamics, obscures transmission lags, and requires extending the time series back into the past to add degrees of freedom. This means that the analysis may not capture more recent relationships brought about by changes in the structure of these economies and by increasing integration. On the other extreme, monthly data are noisy, and can be inconsistent with the annual data.

This paper reconciles these difficulties by using quarterly real GDP data for most countries in the region, as the series have become long enough to perform econometric analysis. For countries not publishing quarterly real GDP (Guatemala and Honduras), the index of monthly activity (IMAE, Índice Mensual de Actividad Económica) was used to construct a quarterly profile for real GDP that is consistent with the annual real growth rate. ${ }^{7}$ While the series do not always cover all sectors of the economy, are volatile, and are not perfectly correlated with annual real GDP growth, they allow for a more in-depth exploration of the recent past and a richer lag structure in the analysis, while still allowing the results to be expressed in the widely-understood terms of real GDP growth. Further details on the transformation of these monthly series are given in Appendix I.

\section{A. Previous Work on Central American Business Cycles}

Kose, Rebucci, and Schipke (2005) document an increased correlation in CAFTA-DR and U.S. annual real GDP growth even before negotiation of the agreement. Using a vector autoregression (VAR) containing U.S., Mexican, and CAFTA-DR real GDP, they find that on average external shocks account for one quarter and regional shocks one half of volatility among the countries of the region. They also use a general equilibrium model to predict that CAFTA-DR would cause a significant increase in the effects of U.S. shocks on the region. Iraheta (2008) estimates a similar VAR, but finds domestic shocks to be more important than extra-regional or regional ones. The average elasticity of activity in the region is found to be around 0.4 to U.S. shocks, and 0.2 to shocks elsewhere in the region.

Fiess (2007) presents measures of business cycle synchronization among Central American countries, as well as linkages with industrial and other Latin American countries. Using filtered annual data from 1965-2005, he finds significant correlations ranging from 0.4 to 0.6 among Costa Rica, El Salvador, Guatemala, and Honduras. Some of this regional comovement represents a common response to U.S. activity, with which the region's growth correlations lie between 0.5 and $0.7 .^{8}$ He estimates the elasticity of economic activity in the region to U.S. cycles and finds that it has increased since 1990 for all countries except Honduras. From 1990 to 2005, a one percent increase in U.S. activity raised growth by more than a percentage point in Costa Rica and Panama, by 0.7 percent in Guatemala, and by 0.4 to 0.5 percent in El Salvador, Honduras, and Nicaragua.

\footnotetext{
${ }^{7}$ Panama produces quarterly real GDP dating back to 2003. Data were extended back to 1999 using its monthly index of economic activity, and to 1992 using an index of manufacturing production.

${ }^{8}$ He also performs a spectral analysis of monthly economic activity data since 1995 . All the coherences among Central American countries and between the region and the United States lie between 0.3 and 0.6.
} 
Roache (2008a), using unfiltered annual data for Central America and Panama from 1950-2006, finds lower correlations but still evidence of linkages among Costa Rica, El Salvador, and Guatemala, even when controlling for the U.S. cycle. He decomposes each country's real GDP into trend and cyclical components using the Vahid and Engle (1993) common cycle model and provides evidence for the existence of four common trends and three common cycles among the seven countries (including the United States), although the estimated trend components are highly volatile. This method yields average cyclical correlations with the United States of 0.7 since 1950 and 0.8 since 1995. The average correlations among the Central American countries are 0.5 to 0.6. Roache (2008b) uses the resulting cyclical and trend components to estimate elasticities to U.S. cyclical and trend growth over the 1950-2006 period using ordinary least squares. The average cyclical elasticity is 0.5 , and the average trend elasticity is 0.1 . However, interpretation of the overall elasticity with respect to U.S. activity is complicated by the decomposition of growth into its cyclical and trend components, and the large contribution of trend growth to volatility casts some uncertainty on the interpretation of the decomposition.

Overall, these studies have found that synchronization among the countries of the region is moderate, but does not rise to the levels seen for more highly integrated areas, such as within the Euro Zone or between Mexico and the United States (see Kim and Papi, 2005). Linkages to U.S. activity appear to have become stronger since the mid-1990s, even before negotiation of U.S. FTAs, although Baroni (2008) notes that part of the increased correlation can be attributed to the end to the domestic armed conflicts experienced in the 1980s.

\section{B. Influence of the U.S. Cycle}

Despite the region's sizable links to the United States, the correlation of economic activity with U.S. growth is relatively low-averaging 0.17 for annual data since 1950, and roughly similar since 1995 (Table 3). The correlations on quarterly data since 1995 are below those of other countries with strong U.S. ties- 0.43 for the euro area, 0.71 for the United Kingdom, 0.67 for Canada, and 0.60 for Mexico. ${ }^{9}$

The economies of the region appear to move more closely with U.S. industrial production than U.S. GDP. This stands to reason, given the importance to the U.S. economy of service industries, whose output relies less on tradable goods, while industrial production is focused on sectors of the economy that rely more heavily on traded inputs, which should affect more directly imports from Central America. As expected, fluctuations in U.S. activity have a larger impact on the region's exports than on other areas of the economy, with significant correlations between U.S. industrial production and real exports since 1995 for Costa Rica, the Dominican Republic, El Salvador, and Guatemala. ${ }^{10}$

\footnotetext{
${ }^{9}$ Idiosyncratic country factors like natural disasters, or currency or banking crises account for some of the low correlations, but adjusting for those factors would still leave business cycle co-movement below the levels seen for the other countries reported here.

${ }^{10}$ Nevertheless, the anaylsis here focuses on real GDP, given its importance as a policy variable and the wider availability of real GDP forecasts.
} 
Table 3. Real GDP Growth Correlations With the United States

(coefficients in bold are statistically significant at the 5 percent level)

\begin{tabular}{|c|c|c|c|c|c|c|c|c|c|}
\hline & CRI & DOM & SLV & GTM & HND & NIC & PAN & $\begin{array}{c}\text { Simple } \\
\text { average }\end{array}$ & $\begin{array}{c}\text { PPP- } \\
\text { weighted } \\
\text { aggregate }\end{array}$ \\
\hline \multicolumn{10}{|c|}{ 1951-2008, annual } \\
\hline U.S. real GDP & 0.33 & -0.13 & 0.36 & 0.16 & 0.43 & 0.06 & -0.02 & 0.17 & 0.26 \\
\hline U.S. IP & 0.34 & -0.08 & 0.39 & 0.31 & 0.48 & 0.11 & 0.08 & 0.23 & 0.36 \\
\hline \multicolumn{10}{|c|}{ 1995-2008, annual } \\
\hline U.S. real GDP & 0.35 & 0.25 & 0.11 & -0.08 & -0.21 & 0.58 & 0.09 & 0.15 & 0.20 \\
\hline U.S. IP & 0.36 & 0.42 & 0.44 & 0.15 & -0.01 & 0.54 & 0.20 & 0.30 & 0.41 \\
\hline \multicolumn{10}{|c|}{ Quarterly data, 1995-2008, y/y } \\
\hline U.S. real GDP & 0.29 & 0.11 & 0.05 & 0.14 & -0.20 & 0.25 & 0.33 & 0.11 & 0.16 \\
\hline U.S. IP & 0.32 & 0.27 & 0.39 & 0.14 & 0.06 & 0.25 & 0.39 & 0.24 & 0.36 \\
\hline \multicolumn{10}{|c|}{ Real Exports, 1995-2008, annual } \\
\hline U.S. real GDP & 0.63 & 0.67 & 0.46 & 0.36 & -0.18 & 0.23 & 0.12 & 0.33 & 0.49 \\
\hline U.S. IP & 0.67 & 0.78 & 0.64 & 0.58 & 0.10 & 0.41 & 0.01 & 0.46 & 0.73 \\
\hline
\end{tabular}

Source: IMF staff calculations.

\section{Synchronization of Central American Cycles}

The period through the early 1970s was marked by strong growth on average, and by the highest year-to-year volatility for most countries in the region (Table 4, Figure 6). There was a generalized downturn in the early 1980s, coinciding with a double-dip recession in the United States, the Latin American debt crisis, and the onset of armed conflict in some countries. Growth remained subdued until the 1990s, when activity began to expand at a rate exceeding the long-term average in the midst of a stable external and domestic environment. The slowdown in the early 2000s was less pronounced but still affected all countries. Since the mid 1990s, volatility by any measure has fallen in all countries, and

Table 4. Volatility of Economic Growth (standard deviation of change in annual real GDP growth) 1951-2008 1951-1973 1974-1994 1995-2008

\begin{tabular}{lrrrl}
\hline Costa Rica & 5.4 & 7.2 & 4.4 & 3.3 \\
Dominican Republic & 7.3 & 10.5 & 5.2 & 3.6 \\
El Salvador & 3.1 & 3.4 & 3.4 & 1.7 \\
Guatemala & 2.4 & 2.9 & 2.4 & 1.3 \\
Honduras & 4.3 & 4.8 & 4.7 & 3.2 \\
Nicaragua & 7.2 & 5.1 & 10.7 & 2.0 \\
Panama & 4.5 & 3.9 & 5.9 & 3.3 \\
Simple average & 4.9 & 5.4 & 5.2 & 2.6 \\
\hline
\end{tabular}

Source: IMF staff calculations. negative outcomes have been less frequent. The annual figures through 2008 show only the initial wave of the impact from the global recession, as the economies of the region were not as heavily affected until late in the year. 
Figure 6. Real GDP Growth

(annual percent change)
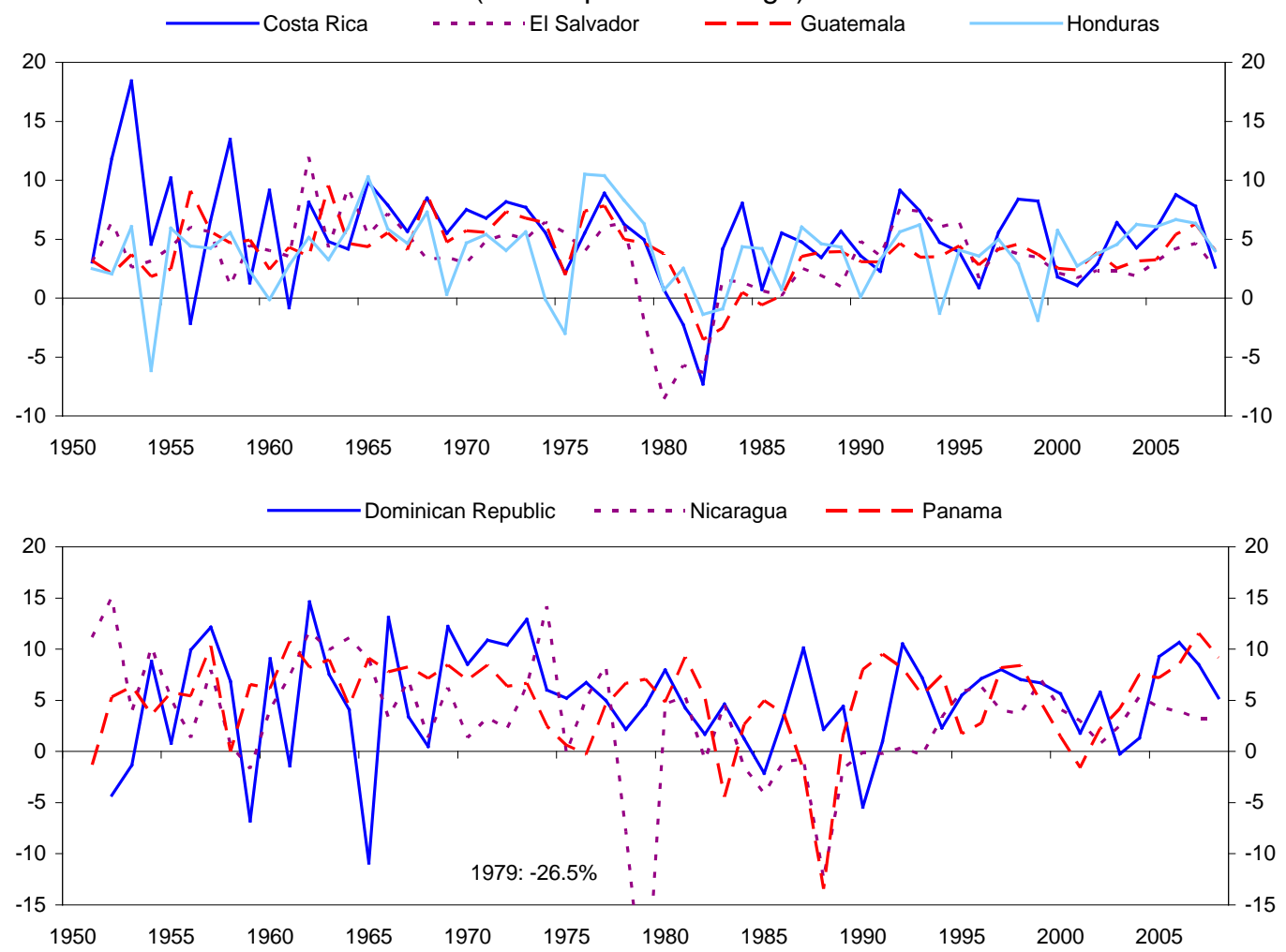

Source: IMF, International Financial Statistics ; IMF, World Economic Outlook; World Bank Development Indicators; and IMF staff calculations.

Table 5 shows real GDP growth correlations within the region. Consistent with Roache (2008a) and Fiess (2007), correlations across countries average only about 0.2 over the full sample. Synchronization has been higher since 1995, but the average correlation is still only 0.3 , on average. Quarterly data show statistically significant correlations among many countries of the region, with cycles in Honduras and Nicaragua the most idiosyncratic.

Given this pattern of linkages, a substantial portion of the common movements in Central American business cycles could be the result of similar responses to external shocks. Both Fiess (2007) and Roache (2008a) regress Central American growth on U.S. growth and show that correlations across the region are lower excluding the U.S. effect, but that activity elsewhere in the region is still a relevant determinant of growth for many countries. 
Table 5. Real GDP Growth Correlations Within Central America (coefficients in bold are statistically significant at the 5 percent level)

\begin{tabular}{|c|c|c|c|c|c|c|c|}
\hline & CRI & DOM & SLV & GTM & HND & NIC & PAN \\
\hline \multicolumn{8}{|l|}{ 1951-2008, annual } \\
\hline $\begin{array}{l}\text { Costa Rica } \\
\text { Dominican Republic }\end{array}$ & 0.08 & & & & & & \\
\hline El Salvador & 0.43 & 0.16 & & & & & \\
\hline Guatemala & 0.30 & 0.30 & 0.45 & & & & \\
\hline Honduras & 0.35 & -0.02 & 0.24 & 0.47 & & & \\
\hline Nicaragua & 0.14 & 0.12 & 0.34 & 0.11 & -0.14 & & \\
\hline Panama & 0.12 & 0.05 & 0.17 & 0.26 & 0.12 & 0.20 & \\
\hline Simple average & 0.24 & 0.12 & 0.30 & 0.32 & 0.17 & 0.13 & 0.15 \\
\hline \multicolumn{8}{|l|}{ 1995-2008, аппиаl } \\
\hline Dominican Republic & 0.40 & & & & & & \\
\hline El Salvador & 0.52 & 0.48 & & & & & \\
\hline Guatemala & 0.63 & 0.63 & 0.73 & & & & \\
\hline Honduras & -0.03 & 0.14 & 0.07 & 0.21 & & & \\
\hline Nicaragua & 0.07 & 0.17 & 0.21 & -0.09 & -0.33 & & \\
\hline Panama & 0.66 & 0.46 & 0.32 & 0.70 & 0.34 & -0.02 & \\
\hline Simple average & 0.37 & 0.38 & 0.39 & 0.47 & 0.07 & 0.00 & 0.41 \\
\hline \multicolumn{8}{|c|}{ Quarterly data, 1995-2008, y/y } \\
\hline \multicolumn{8}{|c|}{ Costa Rica } \\
\hline Dominican Republic & 0.33 & & & & & & \\
\hline El Salvador & 0.53 & 0.42 & & & & & \\
\hline Guatemala & 0.32 & 0.45 & 0.25 & & & & \\
\hline Honduras & 0.00 & 0.05 & 0.04 & 0.00 & & & \\
\hline Nicaragua & 0.26 & 0.06 & 0.31 & -0.01 & -0.11 & & \\
\hline Panama & 0.56 & 0.25 & 0.26 & 0.36 & 0.32 & 0.08 & \\
\hline Simple average & 0.29 & 0.26 & 0.31 & 0.20 & 0.00 & 0.10 & 0.30 \\
\hline
\end{tabular}

Source: IMF staff calculations.

\section{EFFECTS OF EXTERNAL SHOCKS}

This section reports on attempts to try to identify the response of Central American economic activity to external shocks. Previous work has focused largely on the effects of U.S. shocks on Central America, within models in which the United States was treated as the "rest of the world.” This paper extends the analysis to other regions for two purposes. First, while U.S. links predominate, fluctuations elsewhere can also be expected to affect Central America, especially since trade and financial links with other regions have increased in recent decades. Second, the large country-small country framework used in previous studies fails to control for the effects that other regions, or global exogenous shocks, could have on the United States, opening up the possibility for omitted variable bias. 


\section{A. Structural VAR Methodology and Data}

As noted, the analysis in this paper employs a structural vector autoregression (SVAR) framework. The main advantage of an SVAR-based analysis compared to other methodologies is its ability to incorporate interdependencies among the variables. Common movements in economic growth could result from the contributions of global shocks, similar responses to shocks to other regions, or idiosyncratic country shocks that happen to be correlated. In a setting in which multiple regions affect activity in Central America, the SVAR takes into account interactions between those regions, thus tracing the effects of each shock back to the appropriate source. Including lags to allow for the transmission of shocks in prior periods, the system of equations under analysis becomes:

$$
X_{t}=\sum_{i=1}^{m} A_{i} X_{t-i}+v_{t}
$$

Where $X$ is a vector including GDP growth for each region, $A$ is a vector of coefficients, $v$ is a vector of error terms, and $m$ is the number of lags in the system. Coefficients in $A$ can be set to zero, so that there is no direct impact of economic activity between particular regions.

One difficulty not encountered in OLS or a large country-small country framework is the identification of the source of contemporaneous correlation across countries. ${ }^{11}$ The SVAR in equation (1) establishes relationships between the current and past values of the variables in the system, but does not identify relationships across variables in the current period. In order to obtain estimates of the response to one variable given a shock to one of the other variables in the system, contemporaneous movements across variables need to be decomposed into shocks to that variable and responses to shocks to other variables during the same period, as well as to lagged shocks.

This paper uses Cholesky decompositions to determine the drivers of contemporaneous correlation across countries. This technique assumes that the correlation between two variables is driven by the variable ordered first in the SVAR (see Sims, 1980). Once the shocks are orthogonalized using this technique, the coefficients of the SVAR are applied to compute the impulse-response function (IRF) - the time path of the response of any variable to a shock to any other variable. Previous work has highlighted the importance of U.S. shocks for economic activity in other regions, with little feedback in the other direction (Bayoumi and Swiston, 2009). This, along with the dominant share of U.S. trade and financial linkages noted earlier, justifies placing the United States first in the ordering. Ordering among the other regions is based on weight in the global economy, but results for Central America were not sensitive to variation in the ordering of these regions.

\footnotetext{
${ }^{11}$ In either case, the analyst has to make an explicit or implicit assumption that is reflected in the structure of the model.
} 
Given the patterns of integration described earlier, system (1) includes four major regions:

1) the United States; ${ }^{12}$

2) advanced economies except Japan (Australia, Canada, Denmark, the euro area, New Zealand, Norway, Sweden, Switzerland, and the United Kingdom);

3) Asia including Japan (also includes China, Hong Kong, India, Indonesia, Korea, Malaysia, the Philippines, Singapore, Taiwan P.o.C., and Thailand);

4) Large emerging Western Hemisphere countries (Argentina, Brazil, Chile, Colombia, Mexico, Peru, and Uruguay).

The Asian and Western Hemisphere aggregates are constructed by weighting the growth rates of the individual countries by their GDP at purchasing power parity (PPP). One role of the advanced economies aggregate is to proxy for a global shock; however, a PPP approach would give the euro area a weight of two-thirds and swamp the variation in other countries. To avoid this, the growth rates of each country were weighted equally. While a spike in the growth rate in one individual country could be seen as the result of an idiosyncratic country shock, a generalized synchronous movement is more likely to capture global—or, in the case of the Asian and Western Hemisphere aggregates, regional-factors. ${ }^{13}$ Central America can safely be assumed to not drive the economic activity of the other regions included here, so it is always ordered last in the SVAR, and its impact on other regions is set to zero by restricting the appropriate coefficients in the model.

The SVARs are run on quarterly real GDP growth since 1994, with the sample length constrained by the availability of quarterly real GDP series or high-frequency activity indicators for the Central American countries. ${ }^{14}$ Using quarterly data is important for capturing within-year linkages, as well as providing enough degrees of freedom for estimation. While the sample is still small, this does minimize the risk of structural change in the economic relationships under analysis. The results of standard tests varied by country, generally selecting anywhere from 1 to 4 lags, but four lags were included in all runs for uniformity, as well as a priori assumptions about the amount of time necessary for the transmission of shocks across regions. The estimation period of the models thus spans from the second quarter of 1995 through the second quarter of 2009.

\footnotetext{
12 The results are insensitive to placing the United States behind the advanced economies aggregate.

${ }^{13}$ Asia and the Western Hemisphere are only allowed to have a direct impact on the Central American country under analysis when they account for 5 percent or more of the merchandise trade with the country in question. This assumption does not greatly affect the results but minimizes the possibility of spurious correlations.

${ }^{14}$ Quarterly growth rates of seasonally adjusted data were used. This avoids the introduction of any bias related to detrending of the data. While there was some evidence of cointegration of economic activity across regions, estimates using error-correction models did not differ from those reported here.
} 


\section{B. Response of Central American Activity to External Shocks}

Figure 7 shows impulse-response functions (IRFs) tracing out the cumulative impact on Central American real GDP of one standard deviation shocks to real GDP in the major regions. Standard error bands encompassing the 95 percent confidence interval are also shown.

Figure 7. Real GDP Spillovers From Major Regions (cumulative response, in percentage points, to one standard deviation shock)
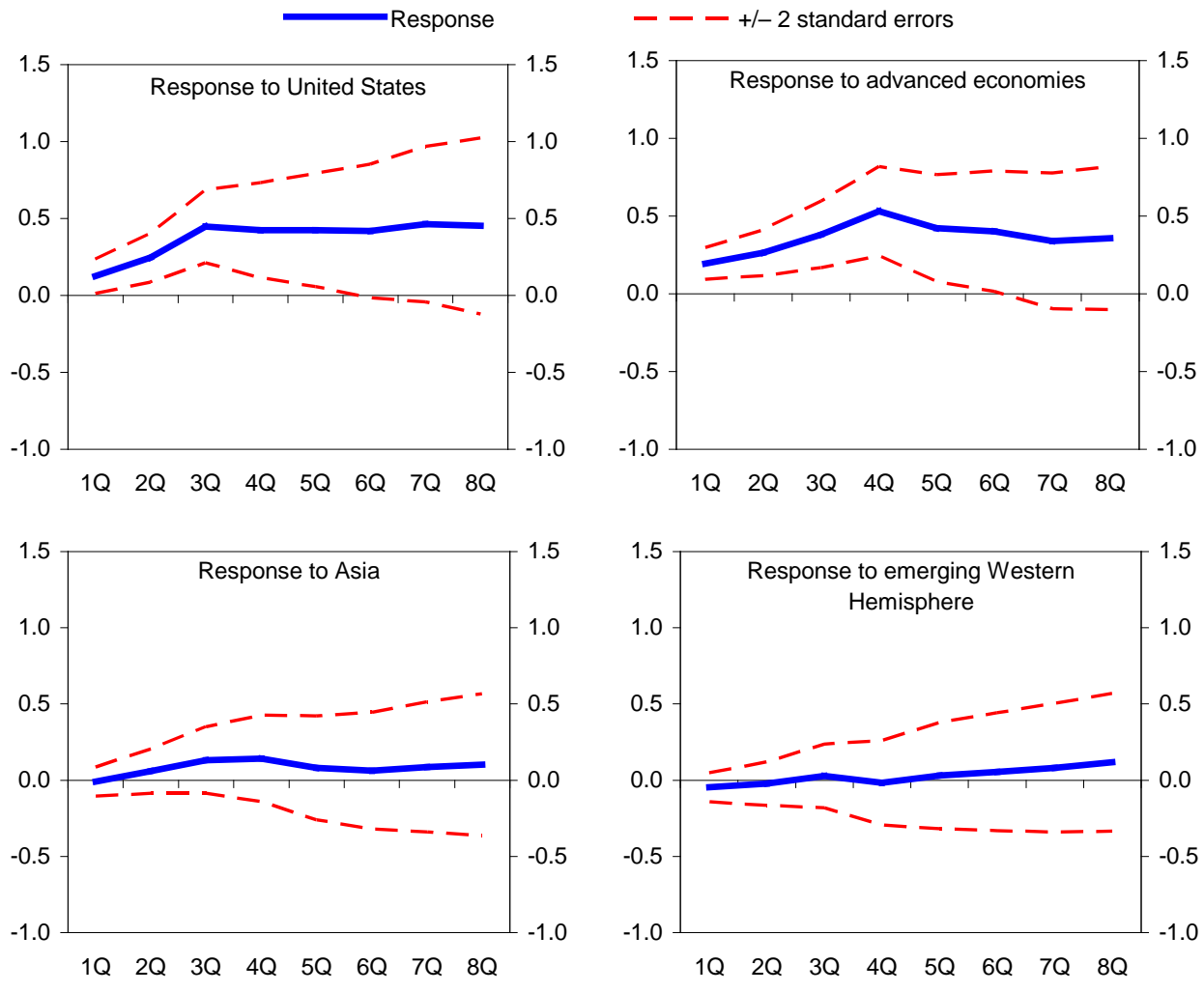

Source: IMF staff calculations.

A one standard deviation positive shock to U.S. real GDP is associated with a gradual and statistically significant rise in activity in Central America, adding about $1 / 2$ percent to real GDP in the year after the shock. Given that the typical U.S. shock is slightly less than $1 / 2$ percent on impact and averages 0.6 over the first year, the elasticity of the Central American cycle to the U.S. cycle is 0.8, slightly higher than the estimates in Roache (2008a). The gradual nature of the pass-through from U.S. to Central American activity underscores the importance of both current and past U.S. developments in the outlook for the region.

Shocks to other advanced economies have a similar effect on Central American activity, reaching about a cumulative 0.5 percent four quarters after the initial shock. Their impact is also statistically significant. Central America’s response to Asian and Western Hemisphere 
shocks is smaller and not significant. Specifications containing only the CAFTA-DR countries or only the CAFTA countries gave similar results.

\section{Spillovers to Individual Central American Countries}

Spillovers to the individual countries in the region are estimated using the same methodology, expanding the number of countries or regions under analysis to six. Each individual Central American country is placed last in an SVAR with the four major regions remaining the same, and the fifth region comprising a PPP-weighted aggregate of the other Central American countries. Figure 8 shows the responses without standard error bands, but statistical significance is noted below where applicable.

The results suggest that a one standard deviation positive shock to the U.S. economy raises activity by about a percentage point in Nicaragua and Panama; by between $1 / 2$ and one point in Costa Rica, El Salvador, and Honduras; and by smaller amounts in the Dominican Republic and Guatemala. These spillovers are statistically significant at various horizons for Costa Rica, El Salvador, Honduras, Nicaragua, and Panama. The total impact tends to build within the first few quarters of the shock and stabilize thereafter.

A one standard deviation shock to other advanced countries shifts activity by between $1 / 2$ and one point in Central American countries except Guatemala and Honduras, where the impact is slightly lower, and Panama, where the impact is nil. Spillovers are statistically significant outside of Honduras and Panama. Honduras and Panama are the only economies sensitive to Asia, although the latter is not statistically significant. In the case of Honduras this is more likely because the occurrence of Hurricane Mitch several quarters after the Asian crisis began to hit growth (see Baroni, 2008). Costa Rica, Panama, and, at least for a time, Honduras, are positively affected by activity elsewhere in the Western Hemisphere, but there are no responses that are statistically significant for more than a brief period.

\section{Spillovers Within Central America}

The 6x6 SVAR also allows an examination of the impact of developments within the rest of the region on each individual country, which is relevant given the importance of intraregional trade and financial linkages. The correlation between economic activity in an individual country and the rest of the Central American region is ascribed first to the common effects of U.S. shocks, then to the effects of disturbances among other major regions. The correlation remaining once these effects are accounted for is then ascribed to regional shocks. 
Figure 8. Real GDP Spillovers to Individual Countries (cumulative response, in percentage points, to one standard deviation shock)
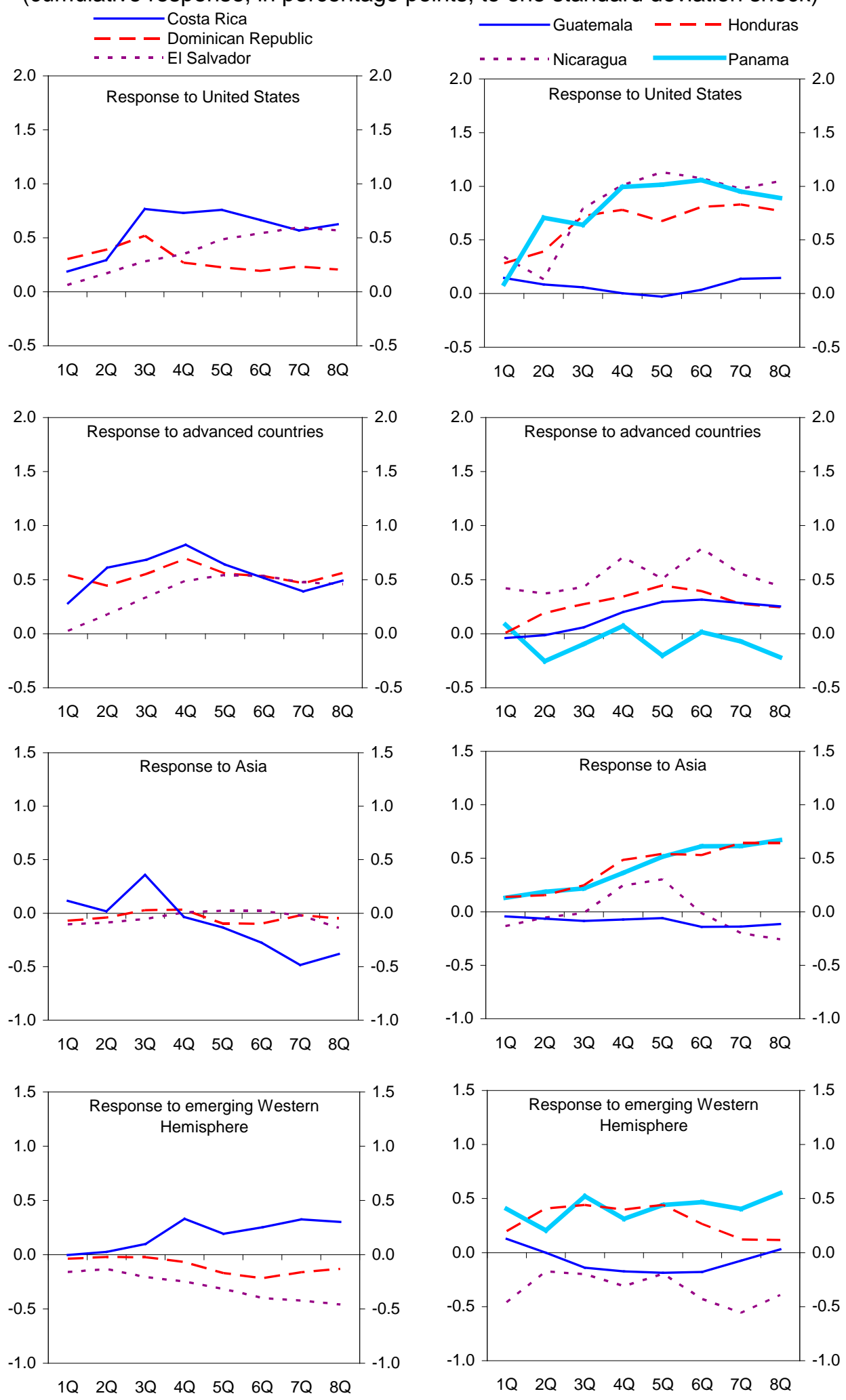

Source: IMF staff calculations. 
While spillovers from major regions drive a significant proportion of the co-movement among economies of the region, there is also evidence of a common business cycle at the regional level, above and beyond the common response to external shocks. Figure 9 shows the responses of activity in each country to the regional aggregate (excluding that particular country). Spillovers from activity elsewhere in the region are noticeable for all countries except Honduras. For Costa Rica, the Dominican Republic, El Salvador, Guatemala, and Nicaragua, a one standard deviation shock to the rest of the region yields a response ranging from 0.2 to 0.4 percent after two years. The responses of El Salvador and Guatemala to the rest of the region are statistically significant.

Figure 9. Real GDP Spillovers Within Central America (cumulative response, in percentage points, to one standard deviation shock)
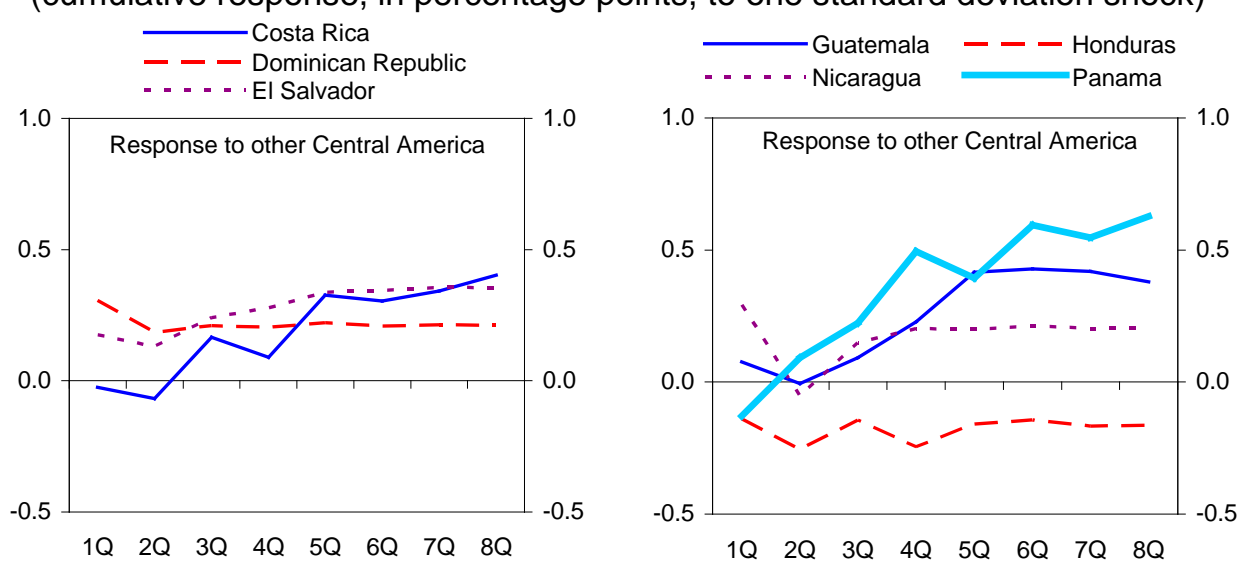

Source: IMF staff calculations.

\section{E. Geographic Drivers of Central American Business Cycles}

Variance decompositions of real GDP growth were performed using the 6x6 SVARs estimated above. These decompositions attribute the variation in domestic activity to the region from which the fluctuations originated. External shocks contribute, on average, about one half of the variation in Central American activity at a two year horizon, ranging from 25 percent for the Dominican Republic to over half for Costa Rica, El Salvador, and Panama (Table 6). Shocks to the Central American region are responsible for 9 percent of business cycle variation, on average, with El Salvador and Guatemala depending the most on regional events. Domestic shocks are responsible for roughly 40 to 50 percent of the typical country's cycle, with a lower contribution in the officially dollarized economies of El Salvador and Panama. However, there is no clear evidence on the effects of dollarization on macroeconomic volatility, since El Salvador ranks second-lowest in volatility while Panama ranks second-highest. 


\begin{tabular}{|lcccc|}
\hline \multicolumn{4}{c|}{ Table 6. Variance Decompositions of Real GDP } \\
\hline \\
\cline { 2 - 3 } & Share of variance at eight quarters explained by: & $\begin{array}{c}\text { Standard deviation of } \\
\text { real GDP growth }\end{array}$ \\
\cline { 2 - 3 } Costernal shocks & Regional shocks & Domestic shocks & & 1.08 \\
Dominican Republic & 54 & 6 & 40 & 0.57 \\
El Salvador & 25 & 5 & 70 & 0.45 \\
Guatemala & 51 & 12 & 37 & 0.43 \\
Honduras & 37 & 17 & 46 & 0.72 \\
Nicaragua & 43 & 5 & 52 & 1.38 \\
Panama & 40 & 6 & 54 & 1.15 \\
Simple average & 66 & 11 & 24 & 0.83 \\
PPP-weighted aggregate & 45 & 9 & 46 & 0.46 \\
\hline Source: IMF staff calculations. & 56 & $\ldots$ & 44 & \\
\hline
\end{tabular}

\section{F. Elasticities of Central American Activity to External Shocks}

The IRFs presented above show the time path of the impact of one standard deviation shocks. These results can be used to compute the elasticity of domestic growth to external growth (Table 7). The figures reported are chosen for the sake of comparability with annual forecasts. Thus, a one percentage point shock to annual real GDP growth in year one is taken as the point of departure, from which three elasticities are calculated: the average response in year one, the additional lagged response in year two, and the total effect on the level of economic activity over two years.

\begin{tabular}{|c|c|c|c|c|c|c|c|c|}
\hline & CRI & DOM & SLV & GTM & HND & NIC & PAN & $\begin{array}{l}\text { PPP-weighted } \\
\text { aggregate }\end{array}$ \\
\hline \multicolumn{9}{|l|}{ Year one } \\
\hline United States & 0.8 & 0.6 & 0.3 & 0.1 & 0.9 & 0.9 & 1.0 & 0.5 \\
\hline Advanced countries & 1.6 & 1.4 & 0.7 & 0.1 & 0.5 & 1.3 & -0.1 & 0.9 \\
\hline Central America & 0.1 & 0.6 & 0.6 & 0.3 & -0.5 & 0.4 & 0.5 & $\ldots$ \\
\hline \multicolumn{9}{|l|}{ Year two (marginal) } \\
\hline United States & 0.3 & -0.3 & 0.5 & 0.0 & 0.4 & 0.8 & 0.6 & 0.2 \\
\hline Advanced countries & -0.2 & -0.1 & 0.6 & 0.6 & 0.4 & 0.2 & -0.2 & 0.1 \\
\hline Central America & 0.8 & 0.0 & 0.4 & 0.8 & 0.1 & 0.2 & 1.0 & $\ldots$ \\
\hline \multicolumn{9}{|l|}{ Total } \\
\hline United States & 1.1 & 0.3 & 0.9 & 0.1 & 1.2 & 1.7 & 1.6 & 0.7 \\
\hline Advanced countries & 1.3 & 1.4 & 1.3 & 0.7 & 0.9 & 1.5 & -0.3 & 1.0 \\
\hline Central America & 0.9 & 0.6 & 0.9 & 1.1 & -0.4 & 0.6 & 1.4 & $\ldots$ \\
\hline
\end{tabular}


A one percentage point positive shock to annual growth in the United States has caused, on average, an increase in growth in year one of 0.7 percent on average, with the impact ranging from 0.1 in Guatemala to 1.0 in Panama. The lagged effects are also relevant outside of the Dominican Republic and Guatemala, raising the impact on the region to 1.0 over a two-year period. The elasticities obtained here are, on average, slightly higher than those obtained by Roache (2008b; see Table 5 above), while there is some variation in the results by country. ${ }^{15}$

An advanced economy shock of one percent is very sizable, amounting to 3 standard deviations over this period, versus 2 standard deviations for the United States. The effects of such a shock are typically front-loaded, and end up having an important impact on all countries except Panama. A Central American shock affects all countries except Honduras, with the effects more drawn out than those of a U.S. or advanced economy shock.

\section{G. Impact of the 2008-09 Crisis}

The models estimated above can be used to generate predictions for the path of real GDP in the region, given the performance of external demand. For example, Figure 10 compares the actual path of activity to the performance of in-sample real GDP forecasts starting in the first quarter of 2008, indexing both series to the fourth quarter of 2007. The PPP-weighted regional aggregate grew 3 percent over this period, compared to a model-based forecast of 5 percent. Growth in Costa Rica, the Dominican Republic, and Nicaragua was over-predicted by the model, while forecasts for El Salvador, Guatemala, Honduras, and Panama tracked actual developments quite closely. ${ }^{16}$

The impulse-response functions estimated above can also be used to quantify the impact of the global financial crisis on activity in Central America. The coefficients from these IRFs were applied to the residuals from the associated SVARs to trace out the time path of the impact of the shock in each period, starting with the first quarter of 2008, and ending with the second quarter of 2009. Given the lags typical in the transmission of external shocks, estimates of their effects were carried through to the end of 2009. This produced an estimate of the crisis' impact on real GDP in the region and in each country.

The lines labeled "Total" in Figure 11 show the estimated cumulative impact of shocks to the United States and other advanced economies. Total spillovers remained low through the first half of 2008, coinciding with a mild contraction in the United States and some growth in other advanced economies. As the downturn intensified and spread in the second half of

\footnotetext{
${ }^{15}$ Multiple factors could be behind the different results: first, this study uses quarterly data beginning in 1995, while Roache's (2008b) estimation used annual data from 1950-2006; second, this analysis controls for the effects of other regions on the U.S. and Central American economies, while Roache's does not contain other regions; and finally, this study does not distinguish between the elasticity to trend and cyclical growth, while Roache's do. The last factor complicates the interpretation of those elasticities in the midst of the simultaneous downturn in trend and cyclical growth that typically occurs in U.S. recessions, including the most recent one.

${ }^{16}$ The model predictions do not account for policy responses or idiosyncratic factors at the country level, although the former would tend to lead the model to under-predict growth given the countercyclical response of most countries in the region.
} 
Figure 10. Model Performance During Crisis

(real GDP, 2007Q4 = 100)
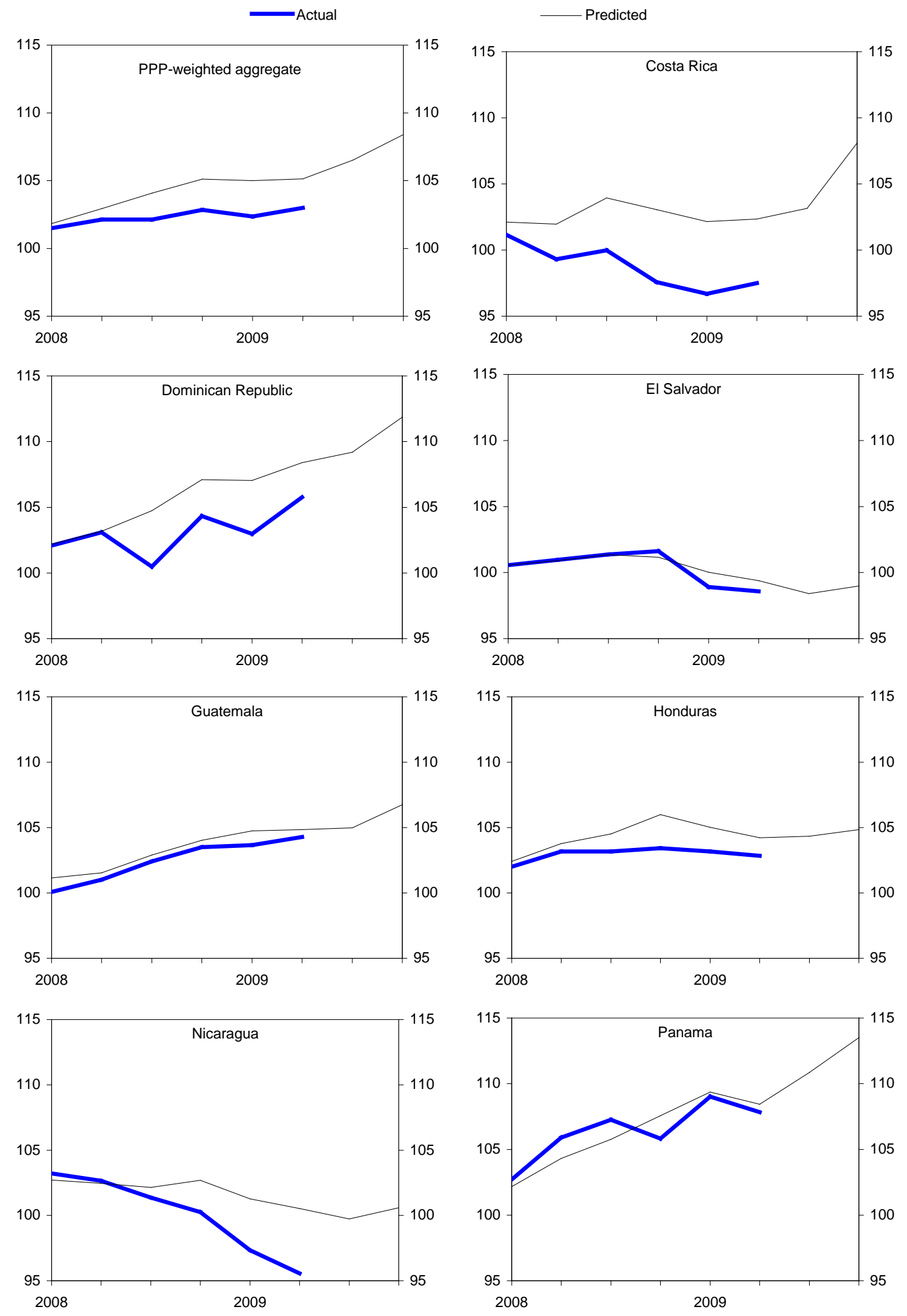

Source: IMF staff calculations. 
Figure 11. Impact of Advanced Country Shocks During the Crisis (contribution to real GDP in percent; cumulative starting in 2008Q1)

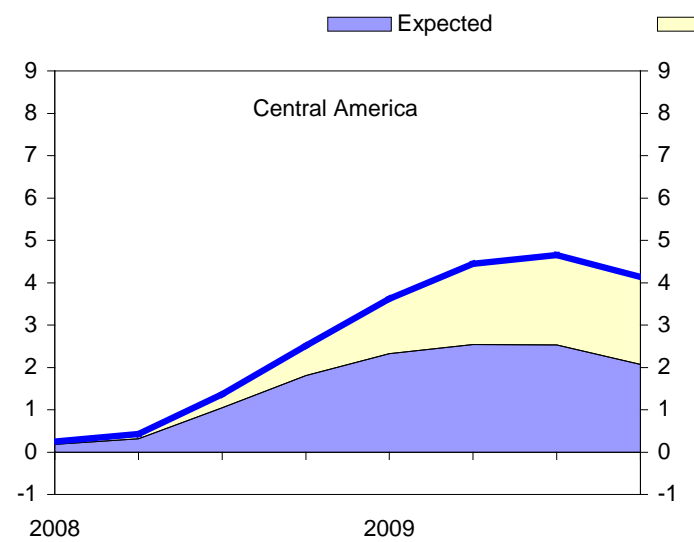

$$
\square \text { Surprise - Total }
$$
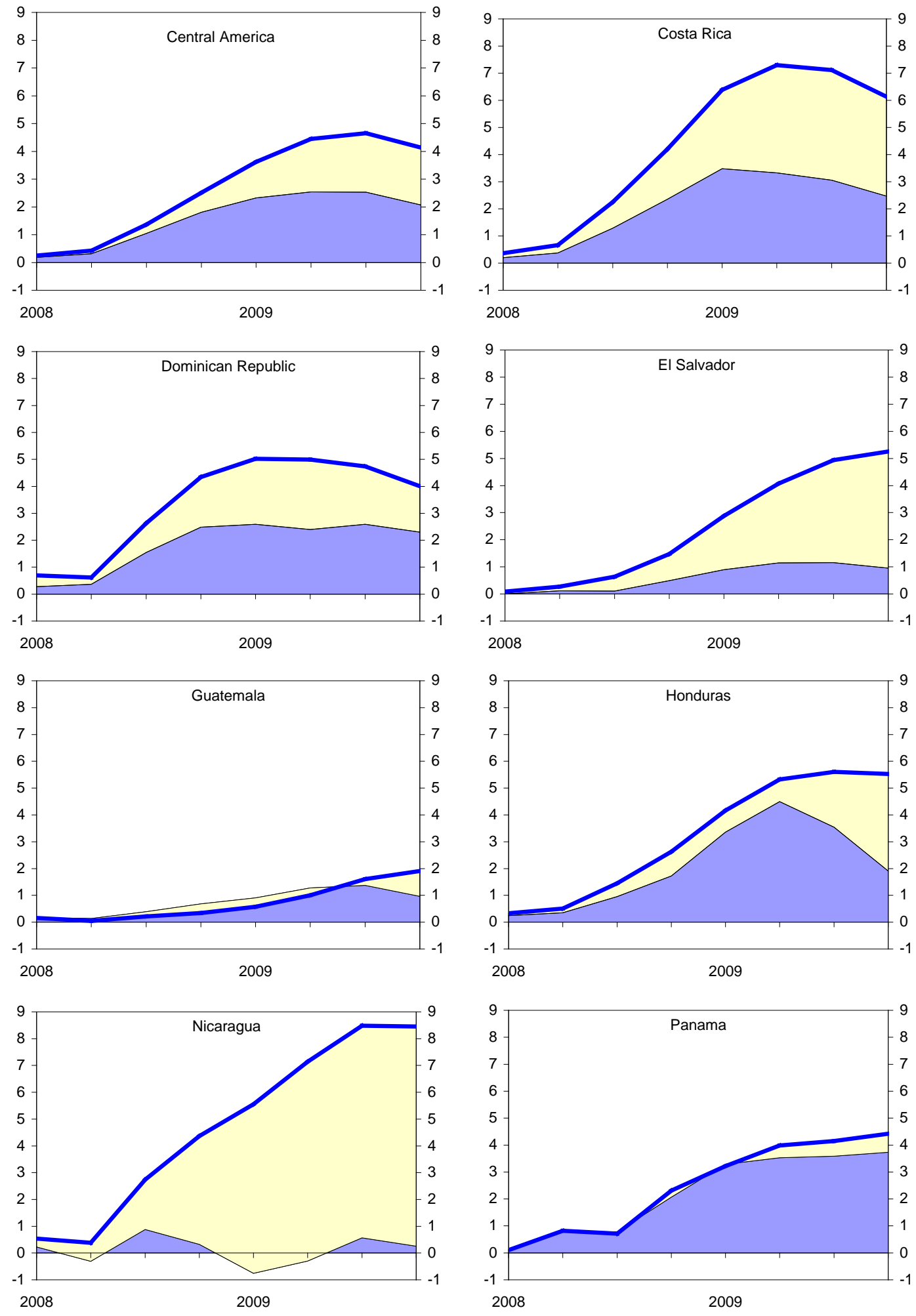

Source: IMF staff calculations. 
2008, the impact on most Central American countries increased. The cumulative effect of the crisis peaked for most countries in mid-2009, with some of the effects expected to revert in the second half of the year, especially in Costa Rica and the Dominican Republic. Nicaragua was the country hit hardest, with U.S. and advanced economy factors reducing real GDP by a total of 8 percent by mid-2009, while the peak impact on Guatemala was only 2 percent. Spillovers to the other countries and the regional aggregate averaged 4 to 6 percent relative to a scenario with no shocks. These magnitudes are in line with forecast revisions observed in the IMF's World Economic Outlook (WEO), as the region's real GDP growth forecasts for 2009 were revised down by an average of 5 percent between the April 2008 and October 2009 WEOs. ${ }^{17}$

Real GDP spillovers from the United States and other advanced economies are also decomposed in Figure 11 into an "expected" component and a "surprise" component. Expected spillovers could have been foreseen ex ante by running the model through the first half of 2008 and applying the associated coefficients to the shocks obtained from the model run over the full sample. This provides an estimate of the impact of the downturn in external demand if it had been known beforehand, given the elasticities available at the beginning of the crisis. The surprise component is the difference between spillovers estimated using the coefficients for the full sample and the expected component. The pre-crisis fit varies widely across countries. Spillovers to Guatemala, Honduras, and Panama have been in line with what would have been predicted ex ante, while spillovers to El Salvador and Nicaragua turned out to be much stronger than pre-crisis elasticities would have predicted. The precrisis model predicted 50 to 60 percent of the impact of the advanced country recession, on average, while 40 to 50 percent would have come as a surprise. Evidence from WEO forecast revisions again supports the broad contours of these findings, as 30 percent of the downward forecast revisions occurred after publication of the April 2009 WEO, when the depth of the advanced country downturn was relatively well established. ${ }^{18}$

The improved model fit as a result of the crisis raises the issue of whether the sensitivity of activity in the region to external shocks will remain high or return to pre-crisis estimates. Correlations of residuals from the model can help shed light on this issue, as changes during recessions could indicate nonlinearities in the transmission of spillovers.

Table 8 shows that the average

\begin{tabular}{|lcc|}
\hline \multicolumn{3}{|c|}{ Table 8. Correlations of Model Residuals } \\
\hline & $\begin{array}{c}\text { Average correlation of residuals for } \\
\text { individual countries with: }\end{array}$ \\
\cline { 2 - 3 } & U.S. residual & Regional residual \\
\hline All observations & 0.22 & 0.17 \\
U.S. expansions only & 0.20 & 0.16 \\
U.S. recessions only & 0.28 & 0.17 \\
2001 recession & 0.05 & 0.26 \\
2008-9 recession & 0.36 & -0.01 \\
\hline Source: IMF staff calculations. & \\
\hline
\end{tabular}

\footnotetext{
17 The model estimates do not account for policy responses made in order to mitigate the impact of external shocks, while the forecasts would account for the effects of these policies.

${ }^{18}$ The timing is not exact, as the forecasts were finalized before first quarter data for advanced economies was released. At the same time, advanced economy growth in the second half of 2009 was revised up after the April 2009 WEO, lending support to the argument that the 30 percent figure constitutes a lower bound for surprise spillovers to the region.
} 
correlation between U.S. and Central American residuals is only slightly higher for U.S. recessions than for U.S. expansions, but that these correlations differed across the two recessions in the sample. Residuals for individual Central American countries were not highly correlated with the negative U.S. residuals during the 2001 recession, but were positively correlated with the residual from the regional aggregate. This is a possible sign that unexplained factors correlated across countries in the region helped to support activity. The converse occurred during the 2008-2009 recession. Residuals were not correlated within the region, but did tend to be correlated with the negative U.S. residuals. Factors not explained by the model but correlated with U.S. shocks tended to reduce activity in Central America, suggesting that idiosyncratic features of the crisis were responsible for the underperformance of growth in the region. If these unexplained factors dissipate once the crisis fully subsides, this suggests a return to less intense spillovers, although this result is tentative because of the low number of independent observations on which the finding is based.

\section{Transmission ChanNels for EXTERnAl GrowTH SPILlovers}

This section attributes the growth spillovers identified in the previous section to the channels responsible for the transmission of the shock. The SVARs are augmented with data on various transmission channels as exogenous variables, one at a time, as in Bayoumi and Swiston (2009). The contribution of each channel $k$ to the total spillover between two countries $i$ and $j$ is calculated as the following:

$C_{i j, k}=r_{i j}-r_{i j, k}$

This is simply the difference between the overall response of growth in country $i$ to country $j$, minus the response of growth in country $i$ to country $j$ estimated when including the spillover channel as an exogenous variable. The exogenous variables directly account for the impact of that transmission channel on growth, leaving in $r_{i j, k}$ only that part of the response of growth that is not accounted for by the transmission channel. The sum of the contributions across channels is not constrained to add to the IRF that was estimated separately, and thus provides an independent verification of the magnitude of growth spillovers. While this procedure does not account for collinearity among the effects of the various channels, thus tending to overstate the total impact, the results can be seen as a gauge of the relative importance of each transmission channel. ${ }^{19}$ The transmission channels considered in this exercise are trade, commodity prices, financial conditions, and remittances.

\section{A. Identifying the Channels}

In Central America, maquila and other manufacturing industries account for a large —and growing - share of exports, for which there is typically a parallel transaction for imports that

\footnotetext{
${ }^{19}$ Bayoumi and Swiston (2009) enter all channels into the VAR simultaneously to investigate the extent of multicollinearity among the spillover channels. That is not possible in the current exercise because of degrees of freedom constraints in the data.
} 
is netted out of GDP. The contribution of net exports to real GDP growth is thus the most appropriate measure of the effect of fluctuations in international trade on economic activity, and is used to identify trade spillovers. Quarterly national accounts data at constant prices are used for Costa Rica, the Dominican Republic, and Nicaragua. In the absence of this data for the other countries in the region, this paper uses quarterly data on merchandise trade in U.S. dollars, converted into domestic currency and deflated by the domestic CPI.$^{20}$ To identify trade spillovers from the major regions, the contribution of exports to real GDP growth is used. Only the contemporaneous value and first lag are included in order to avoid picking up reverse causality from GDP shocks to exports in future periods (the same applies for the other three channels).

The commodity prices used are the APSP oil price and the S\&P/Goldman Sachs non-energy commodity price index. Because these prices are expressed in U.S. dollars, they are converted into real terms using the U.S. GDP deflator, and entered into the SVAR in quarterly percent changes. Movements in commodity prices brought about by a supply shock will probably have the same impact on foreign commodity importers as they do on activity in the region, generating positive commodity price spillovers. If foreign growth raises commodity prices through a demand shock, then activity in the region would move in the opposite direction, bringing about negative commodity price spillovers.

Financial spillovers could occur through several different channels, including short-term and long-term interest rates, corporate risk spreads, equity prices, and non-price terms of credit availability. Given the number of variables and regions involved, the estimated systems could rapidly exhaust the available degrees of freedom. However, given the preponderance of Central America-U.S. links, the analysis here focuses on U.S. variables. The 3-month LIBOR, the 10-year Treasury yield, and real equity prices are included. The Federal Reserve's Senior Loan Officer Survey is used to capture non-price terms of credit availability (see Swiston, 2008, for an examination of the role of this variable in U.S. financial conditions). ${ }^{21}$ Domestic financial conditions are excluded, as they are assumed to reflect either idiosyncratic domestic factors or the domestic response to external shocks.

For spillovers related to remittances, using real growth rates would bias the results downward because of the structural increase of remittance inflows relative to the size of the region's economies. To better control for this rising trend, this paper uses the quarterly change in the ratio of remittances to the recipient country's GDP. It bears noting that the variables presented here would need to be correlated with both foreign and domestic activity to serve as spillover channels. For remittances, in particular, the theoretical and empirical support for that assumption is weak.

\footnotetext{
${ }^{20}$ The quarterly national accounts data includes trade in services. Services are not included in the data for the other countries.

${ }^{21}$ The survey question used measures the proportion of banks tightening non-price terms for commercial and industrial loans to large firms. Swiston (2008) concludes that this item outperforms other responses in the Senior Loan Officer Survey in terms of its predictive power.
} 
Figure 12. Decomposition of Real GDP Spillovers from the United States
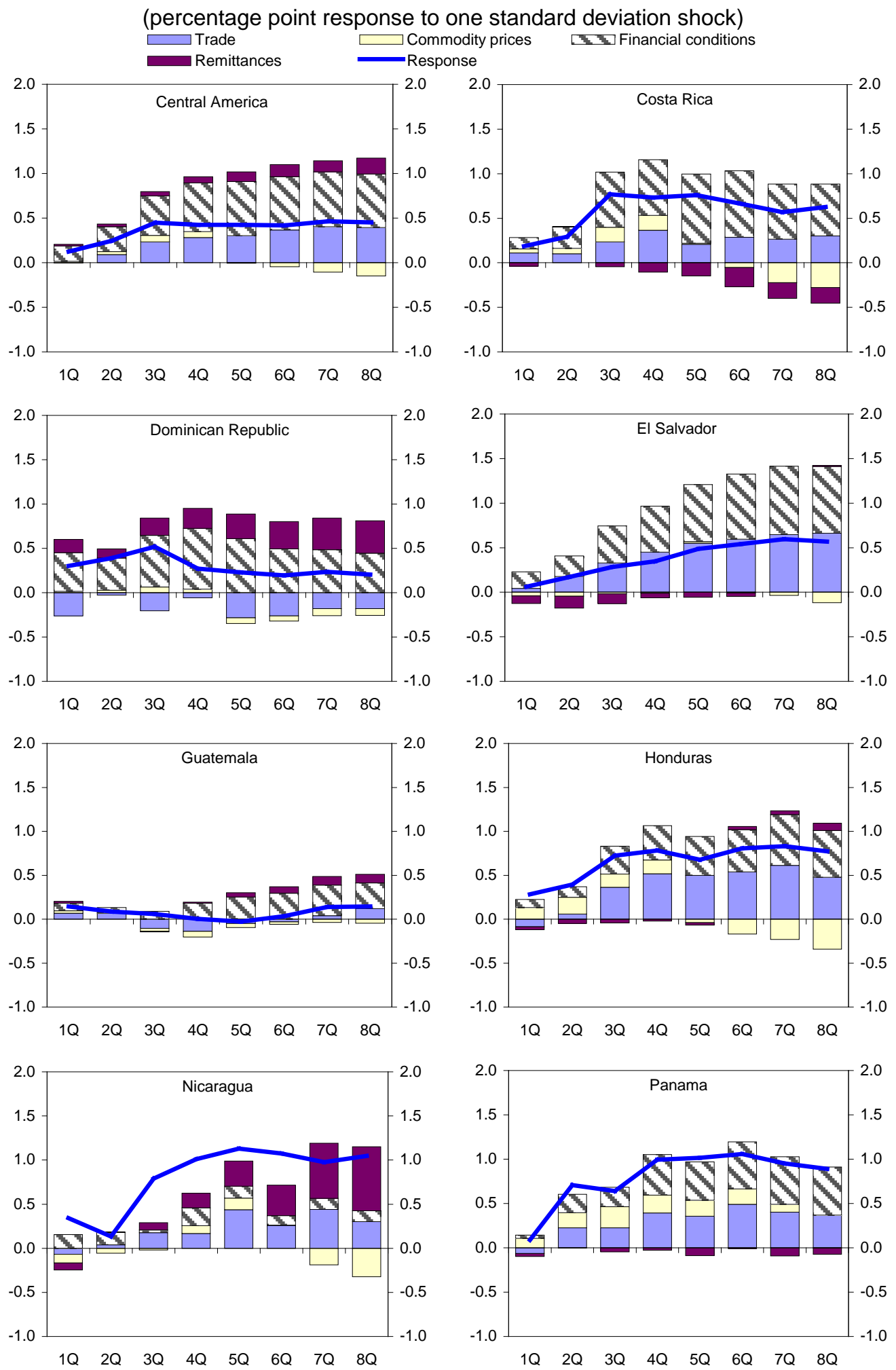

Source: IMF staff calculations. 


\section{B. Decomposition of Spillovers to Central America}

Figure 12 shows a decomposition of spillovers from the United States to the Central American aggregate and to each individual country. The sum of spillovers estimated from the individual channels is not constrained to equal the IRF estimated directly in the previous section. Multicollinearity between channels could therefore lead to the sum of the parts being greater than the whole, while the presence of other unexplained transmission channels could cause the reverse.

For the region as a whole, U.S. financial conditions transmit over half of growth spillovers, while trade channels contribute a third of spillovers. Spillovers through financial and trade channels are important across most of the countries of Central America, while commodity prices and remittances are not typically substantial. The crisis-generated surprises mentioned

earlier were transmitted through both financial and trade channels, as spillovers through these channels were smaller in estimations based on pre-crisis data. This is also consistent with the region's increased level of financial and trade integration. The failure to find a consistent impact from remittances is in line with the existing literature, as noted earlier. This result could stem at least partly from breaks in the data due to improvements in coverage over time, which would tend to obscure the underlying series' correlations with economic activity in source and recipient countries. Also, for countries with flexible exchange rates, a currency depreciation during a downturn could mitigate some of any fall in the U.S. dollar value of remittances. A more complete examination of this transmission channel is an important area for future research.

\section{SUMMARY AND CONCLUSIONS}

The Central American region has become increasingly integrated with the rest of the world, through stronger trade links, rising cross-border financial asset holdings and capital flows, and sharply higher remittance flows. Many of these trends began in the mid-1990s, well before the implementation of free trade agreements with the United States, although these will likely further spur both trade and financial integration in the future.

One policy challenge posed by economic integration is greater exposure to external shocks. The empirical findings of this paper indicate that economic growth in the region depends significantly on external fluctuations, although the short time span over which data is available adds a measure of uncertainty to these inferences. A one percentage point shock to U.S. growth is found to be associated with a response of Central American activity of 0.7 to 1 percent, on average. Global shocks cause fluctuations of a similar magnitude. Spillovers have typically been transmitted through both financial and trade links, while remittances were not found to play an important role in transmitting business cycles across borders. Some evidence was also found of a regional cycle above and beyond the common response to external shocks, as activity elsewhere in the region was found to be important for some countries.

The recent global financial crisis weighed heavily on activity in the region in 2008 and 2009, cutting 2009 growth by an average of 4 to 5 percent. The impact was almost twice as large as elasticities estimated on pre-crisis data would have predicted, and accounted for the majority 
of the observed output slowdown. The extent to which these spillovers were a surprise illustrates the larger-than-expected impact of the recent crisis and raises questions about the region's sensitivity to external growth once the crisis fully subsides. If external spillovers typically intensify during recessions, the absence of any severe recession in advanced economies in the pre-crisis data, combined with the region's increased integration, suggests that the region's response to external shocks will remain high. ${ }^{22}$ However, unexplained factors associated with the recent crisis but not the 2001 recession were found to be important, implying that elasticities during non-crisis periods could once again approach precrisis estimates. This issue remains an important topic for future research.

More explicitly accounting for the impact of external fluctuations could help improve policy design and coordination in the region. The ability to offset the effects of external shocks through countercyclical policies will depend crucially on establishing buffers and addressing vulnerabilities during tranquil periods, so that there exists scope to support the economy when the external environment becomes less favorable. The importance of financial spillovers, especially as seen in the recent crisis, underscores the role financial sector regulatory policy and safety nets could possibly play, alongside the fiscal, monetary, and exchange rate policies normally relied upon (International Monetary Fund 2009).

\footnotetext{
${ }^{22}$ While differences between the Mexican and Central American economies limit somewhat the parallels that can be made, the heightened sensitivity of Mexico's business cycle to that of the United States following the approval of NAFTA suggests that closer integration could contribute to a further increase in synchronization between Central America and the United States in the future.
} 


\section{Appendix I: Constructing GDP-Consistent Quarterly Indicators of Economic Activity}

This paper makes use of the information contained in the monthly series on economic activity by smoothing the data, then using the within-year variation of the transformed series to construct a quarterly indicator that is consistent with annual real GDP growth.

The raw, unadjusted series for each country was first seasonally adjusted using standard X12 procedures, including calendar day and holiday adjustments. This step also conducts tests for, but does not correct, remaining outliers. A second stage procedure adjusts the monthly data for up to four remaining potential sources of further seasonal distortion (not fully accounted for in the X12 adjustment) or excess volatility: 1) leap years; 2) shifts in the timing of Easter; 3) outliers detected by the tests in the first step; and 4) negative autocorrelation in the data, which can be a potential sign of sampling error or other measurement issues. Alterations are only made when a given factor is a statistically significant driver of the data.

The resulting data are then consolidated to quarterly and annual frequency. The quarterly data are standardized, giving them a mean of zero and standard deviation of one. Growth in quarterly activity is then given the same mean as in the annual real GDP data, with the standard deviation equal to the standard deviation of real GDP, scaled up by the ratio of the standard deviation of quarterly activity growth to that of annual activity growth.

The third step generates a series for which the mean and standard deviation of annual growth are approximately equal to those of real GDP. The two annual series do not necessarily move together, as the correlation between their growth rates is 0.4 for Honduras and 0.2 for Guatemala. The difference between the two growth rates, in terms of the mean and standard deviation of real GDP, is thus calculated and used as the measure for a final adjustment. The quarterly growth rates generated in the previous step are adjusted by the measure of the difference, in standard deviations, between the annual growth rates of the two series.

This process raises the correlation between annual real GDP growth and annual smoothed activity growth to 0.8 for Guatemala and 0.9 for Honduras (Table 12). The adjustments balance out to zero over the full sample. Thus, the adjusted series have the same mean and standard deviation as annual real GDP, while taking the within-year profile of the monthly activity index. The smoothed series are 30 to 40 percent less volatile than the raw activity series, which is a plausible magnitude given that for Costa Rica, El Salvador, and Nicaragua, quarterly real GDP is 33 percent less volatile than raw activity, on average.

\begin{tabular}{|c|c|c|c|c|c|c|}
\hline \multicolumn{7}{|c|}{$\begin{array}{l}\text { Table 9. Volatility and Correlations of Activity Indicators, 1995-2008 } \\
\text { (standard deviations and correlations of four-quarter growth rates) }\end{array}$} \\
\hline & \multicolumn{3}{|c|}{ Volatility (standard deviation) } & \multicolumn{3}{|c|}{ Correlation with real GDP } \\
\hline & \multirow{2}{*}{$\begin{array}{l}\text { Raw } \\
\text { activity }\end{array}$} & \multirow{2}{*}{$\begin{array}{l}\text { Real } \\
\text { GDP }\end{array}$} & \multirow{2}{*}{$\begin{array}{l}\text { Smoothed } \\
\text { activity }\end{array}$} & \multicolumn{2}{|c|}{ Raw activity } & \multirow{2}{*}{$\frac{\text { Smoothed activity }}{\text { Annual }}$} \\
\hline & & & & Annual 1/ & Quarterly & \\
\hline Costa Rica & 3.7 & 3.2 & .. & 0.97 & 0.94 & .. \\
\hline El Salvador & 2.9 & 1.4 & .. & 0.92 & 0.80 & .. \\
\hline Guatemala & 2.3 &.. & 1.5 & 0.18 & .. & 0.78 \\
\hline Honduras & 4.6 &.. & 3.2 & 0.46 & .. & 0.89 \\
\hline Nicaragua & 3.7 & 2.5 & .. & 0.83 & 0.49 & .. \\
\hline
\end{tabular}




\section{References}

Árvai, Z., K. Driessen, and İ. Ötker-Robe, 2009, "Regional Financial Interlinkages and Financial Contagion Within Europe,” IMF Working Paper 09/6 (Washington: International Monetary Fund). Available on the Internet: http://www.imf.org/external/pubs/ft/wp/2009/wp0906.pdf.

Bank of Mexico, 2002, "Implications of Financial Liberalization for the Promotion and Allocation of Domestic Saving: The Case of Mexico.” Available on the internet at: http://www.banxico.org.mx/tipo/publicaciones/seminarios/APEC.html.

Baroni, B., 2008, "Los Nuevos Desafíos de Centroamérica Frente a la Recesión de Estados Unidos,” Boletín de Estudios Fiscales No. 9 (Guatemala, Instituto Centroamericano de Estudios Fiscales). Available via the Internet: http://www.icefi.org/index.php?option=com_content\&task=view\&id=19\&Itemid=21.

Bayoumi, T., and A. Swiston, 2009, "Foreign Entanglements: Estimating the Source and Size of Spillovers Across Industrial Countries.” IMF Staff Papers, Vol. 56 (June), pp. 353-383.

Bergin, P., R. Feenstra, and G. Hanson, 2007, "Outsourcing and Volatility: Evidence from Mexico’s Maquiladora Industry,” American Economic Review, Vol. 99 (September), pp. 1664-1671.

Brenner, P. (ed.), 2006, Central America: Structural Foundations for Regional Financial Integration (Washington: International Monetary Fund).

Calderón, C., A. Chong, and E. Stein, 2007, “Trade Intensity and Business Cycle Synchronization: Are Developing Countries Any Different?” Journal of International Economics, Vol. 71 (March), pp. 2-21.

Chami, R., and others, 2008, Macroeconomic Consequences of Remittances. IMF Occasional Paper 259 (Washington: International Monetary Fund).

Chiquiar, D., and M. Ramos-Francia, 2005, "Trade and Business-Cycle Synchronization: Evidence From Mexican and U.S. Manufacturing Industries," North American Journal of Economics and Finance, Vol. 16 (August), pp. 187-216.

Desruelle, D., and A. Schipke, 2008, "Moving Forward With Economic Integration and Cooperation.” In Central America: Economic Progress and Reforms, ed. by D. Desruelle and A. Schipke (Washington: International Monetary Fund).

Fiess, N., 2007, "Business Cycle Synchronization and Regional Integration: A Case Study for Central America,” The World Bank Economic Review, Vol. 21, No. 1, pp. 49-72.

Hornbeck, J., 2004, “The U.S.-Central America Free Trade Agreement (CAFTA): Challenges for Sub-Regional Integration,” Congressional Research Service Report No. RL31870 (Washington). 
Imbs, J., 2006, “The Real Effects of Financial Integration,” Journal of International Economics, Vol. 68 (March), pp. 296-324.

International Monetary Fund, 2009, “Lessons of the Global Crisis for Macroeconomic Policy,” IMF Board Paper. Available via the Internet: http://www.imf.org/external/np/exr/key/finstab.htm.

Iraheta, M., 2008, “Transmisión de los Ciclos Económicos de los Estados Unidos a Centroamérica y República Dominicana,” Central American Monetary Council Working Paper SECMCA II - 2508. Available via the Internet: http://www.secmca.org/Documentos_Trabajo.htm.

Kim, J., and L. Papi, 2005, “Regional Integration and Exchange Rate Arrangements.” In Central America: Global Integration and Regional Cooperation, ed. by M. Rodlauer and A. Schipke (Washington: International Monetary Fund).

Kose, M., G. Meredith, and C. Towe, 2004, "How Has NAFTA Affected the Mexican Economy? Review and Evidence,” IMF Working Paper 04/59 (Washington: International Monetary Fund). Available via the Internet: http://www.imf.org/external/pubs/ft/wp/2004/wp0459.pdf.

Kose, M., A. Rebucci, and A. Schipke, 2005, "Macroeconomic Implications of CAFTADR.” In Central America: Global Integration and Regional Cooperation, ed. by M. Rodlauer and A. Schipke (Washington: International Monetary Fund).

Lederman, D., W. Maloney, and L. Servén, 2003, Lessons from NAFTA for Latin America and the Caribbean (Washington: World Bank).

Magnusson Bernard, K., 2009, “The Impact of U.S. Regional Business Cycles on Remittances to Latin America,” SSE/EFI Working Paper in Economics and Finance No. 710.

Morales, R., and A. Schipke, 2005, “Regional Integration and Financial Systems Issues.” In Central America: Global Integration and Regional Cooperation, ed. by M. Rodlauer and A. Schipke (Washington: International Monetary Fund).

Ratha, D., and W. Shaw, 2007, "South-South Migration and Remittances.” World Bank Working Paper No. 102 (Washington: World Bank). Available via the Internet: http://www.worldbank.org/elibrary.

Reinhart, C., and V. Reinhart, 2008, “Capital Flow Bonanzas: An Encompassing View of the Past and Present,” NBER Working Paper 14321.

Rennhack, R., and M. Nozaki, 2006, “Financial Dollarization in Latin America.” IMF Working Paper 06/7 (Washington: International Monetary Fund). Available via the Internet: http://www.imf.org/external/pubs/ft/wp/2006/wp0607.pdf.

Roache, S., 2008a, “Central America’s Regional Trends and U.S. Cycles.” In Central America: Economic Progress and Reforms, ed. by D. Desruelle and A. Schipke (Washington: International Monetary Fund). 
Roache, S., 2008b, “Central America’s Regional Trends and U.S. Cycles.” IMF Working Paper 08/50 (Washington: International Monetary Fund). Available via the Internet: http://www.imf.org/external/pubs/ft/wp/2008/wp0850.pdf.

Roache, S., and E. Gradzka, 2007, "Do Remittances to Latin America Depend on the U.S. Business Cycle,” IMF Working Paper 07/273 (Washington: International Monetary Fund). Available via the Internet: http://www.imf.org/external/pubs/ft/wp/2007/wp07273.pdf.

Sayan, S., 2006, “Business Cycles and Workers' Remittances: How Do Migrant Workers Respond to Cyclical Movements of GDP at Home?” IMF Working Paper 06/52 (Washington: International Monetary Fund). Available via the Internet: http://www.imf.org/external/pubs/ft/wp/2006/wp0652.pdf.

Schiavo, S., 2008, "Financial Integration, GDP Correlation and the Endogeneity of Optimum Currency Areas,” Economica, Vol. 75 (February), pp. 168-89.

Shah, H., and others, 2008, "Financial Sector Development: Equity and Private Debt Markets.” In Central America: Economic Progress and Reforms, ed. by D. Desruelle and A. Schipke (Washington: International Monetary Fund).

Sims, C., 1980, “Macroeconomics and Reality,” Econometrica, Vol. 48 (January), pp. 1-48.

Sosa, S., 2008, "External Shocks and Business Cycle Fluctuations in Mexico," IMF Working Paper 08/100 (Washington: International Monetary Fund). Available via the Internet: http://www.imf.org/external/pubs/ft/wp/2008/wp08100.pdf.

Storrs, K., and others, 2005, "Central America and the Dominican Republic in the Context of the Free Trade Agreement (DR-CAFTA) with the United States,” Congressional Research Service Report No. RL32322 (Washington).

Swiston, A., 2008, “A Financial Conditions Index for the United States: Putting Credit Where Credit is Due,” IMF Working Paper 08/161 (Washington: International Monetary Fund). Available via the Internet: http://www.imf.org/external/pubs/ft/wp/2008/wp08161.pdf.

Swiston, A., and T. Bayoumi, 2008, “Spillovers Across NAFTA,” IMF Working Paper 08/03 (Washington: International Monetary Fund). Available via the Internet: http://www.imf.org/external/pubs/ft/wp/2008/wp0803.pdf.

Torres, A., and O. Vela, 2003, "Trade Integration and Synchronization Between the Business Cycles of Mexico and the United States," North American Journal of Economics and Finance, Vol. 14 (December), pp. 319-342.

Vahid, F., and R. Engle, 1993, “Common Trends and Common Cycles,” Journal of Applied Econometrics, Vol. 8, No. 4, pp. 341-60.

World Bank, 2005, Global Economic Prospects 2006: Economic Implications of Remittances and Migration (Washington: World Bank). 